\title{
Prins cyclization-mediated stereoselective synthesis of tetrahydropyrans and dihydropyrans: an inspection of twenty years
}

\author{
Asha Budakoti ${ }^{*}$ Pradip Kumar Mondal, Prachi Verma and Jagadish Khamrai
}

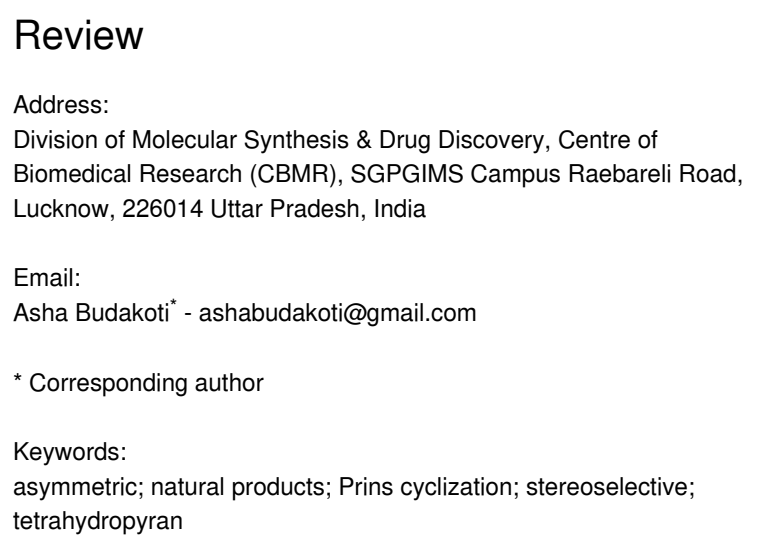

Beilstein J. Org. Chem. 2021, 17, 932-963. https://doi.org/10.3762/bjoc.17.77

Received: 16 January 2021

Accepted: 14 April 2021

Published: 29 April 2021

Associate Editor: S. Bräse

(C) 2021 Budakoti et al.; licensee Beilstein-Institut. License and terms: see end of document.

\begin{abstract}
Functionalized tetrahydropyran (THP) rings are important building blocks and ubiquitous scaffolds in many natural products and active pharmaceutical ingredients (API). Among various established methods, the Prins reaction has emerged as a powerful technique in the stereoselective synthesis of the tetrahydropyran skeleton with various substituents, and the strategy has further been successfully applied in the total synthesis of bioactive macrocycles and related natural products. In this context, hundreds of valuable contributions have already been made in this area, and the present review is intended to provide the systematic assortment of diverse Prins cyclization strategies, covering the literature reports of the last twenty years (from 2000 to 2019), with an aim to give an overview on exciting advancements in this area and designing new strategies for the total synthesis of related natural products.
\end{abstract}

\section{Introduction}

6-Membered saturated oxygen heterocycles, known as tetrahydropyran (THP), are recognized as privileged scaffolds, present in a variety of biologically important natural products, such as polyether antibiotics, marine toxins, pheromones, and pharmaceutical agents. These structural motifs are frequently used as synthons and as key intermediates for natural product synthesis. Therefore, the development of stereoselective synthetic methods for the substituted THP subunit has long been the area of fundamental research in organic chemistry. Thus far, several methods have been devised for the construction of substituted tetrahydropyran rings. Since the year 2000, a number of conceptually different reactions have been developed for the efficient construction of THP rings and were eventually employed in the total synthesis of natural products [1-8]. Prins and related cyclization reactions $[9,10]$, hetero-Diels-Alder cyclization [11], cyclization onto epoxides [12], Petasis-Ferrier rearrangement [13], intramolecular oxa-Michael reactions [14], cyclization through oxidative $\mathrm{C}-\mathrm{H}$ bond functionalization [15], 
ring-closing metathesis (RCM) [16], halo etherification [17], reductive etherification $[18,19]$, and metal-mediated cyclization [20,21], etc. are the most frequent strategies utilized for THP ring construction (Scheme 1). Amongst all, the Prins reaction has proven as a powerful technique in the stereoselective synthesis of the THP key scaffold and its application towards the total synthesis of natural products. Many advancements were also taking place in Prins cyclization methodologies over that period of time. This appraisal aims to bring together the work of many research groups in the area of the development of Prins and related cyclization strategies along with the discussion on the general mechanistic part. We sincerely hope that this review will deliver a snapshot of the up-to-date state of the inventiveness in this field, and most importantly, it will give an inspiration to the reader to take up the challenge and contribute greater advances in this area in the future. This review comprises the literature reports over the last twenty years and its advances. It is likely that some references may have escaped our attention unintentionally, for which we would greatly apologize to those whose contribution in this area has not been included.

\section{Review}

\section{Prins cyclization: general}

For the first time, in 1899, Kriewitz [22] reported the synthesis of unsaturated pinene alcohol through a thermal ene reaction using $\beta$-pinene and paraformaldehyde. After nearly twenty years, Prins explored this reaction further for the synthesis of diol by the condensation of styrene and paraformaldehyde in the presence of a Brønsted acid [23,24]. The major breakthrough for this reaction was reported by Hanschke in 1955, when the THP ring was selectively constructed through a Prins reaction involving 3-butene-1-ol and a variety of aldehydes or ketones in the presence of acid (Scheme 2) [25].

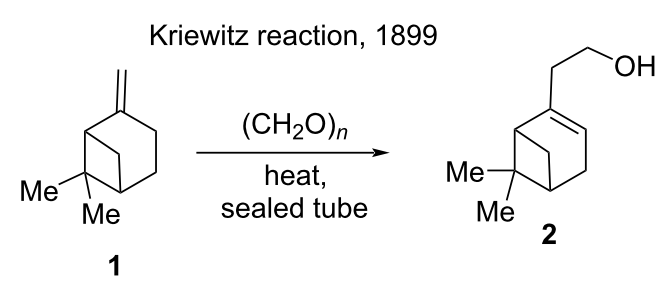

Prins reaction 1919<smiles>C=Cc1ccccc1</smiles>

3

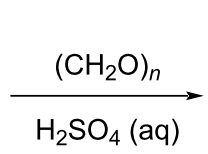

Hanschke reaction 1955<smiles>[R]C(O)CC=C</smiles><smiles>OCCC(O)c1ccccc1</smiles>

4

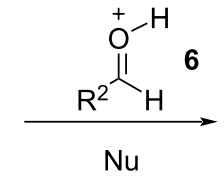

$\mathrm{Nu}$<smiles>[R]C1CC(N)CC([R])O1</smiles>

7
Scheme 2: Developments towards the Prins cyclization.

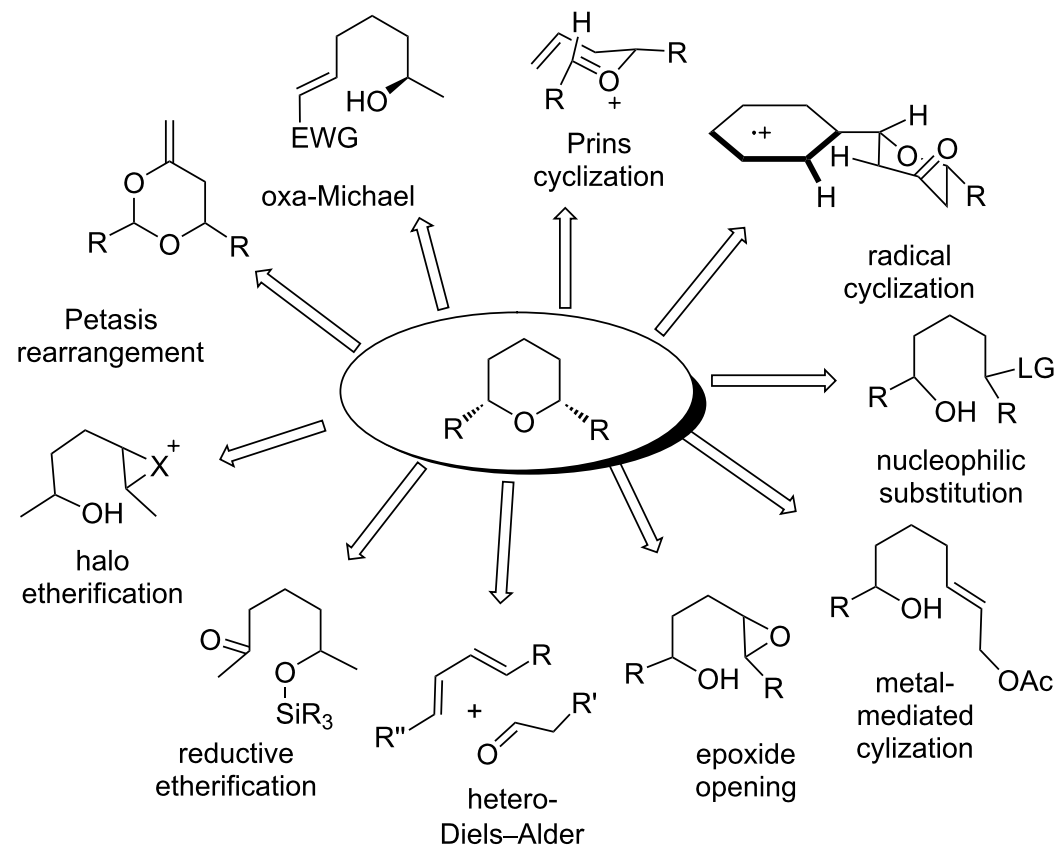


Although the Kriewitz reaction was an ene reaction, the mechanism of the reaction was described to proceed via an oxocarbenium ion intermediate captured by a $\pi$-nucleophile, followed by the addition of an external nucleophile, leading to the formation of products. Since then, the Prins cyclization emerged as the most commonly used strategy for the stereoselective construction of the THP ring, and its application lead to some excellent reviews on the Prins reaction [26,27]. In general, an endo cyclization proceeds via an oxocarbenium ion intermediate in a stereoselective manner for THP ring formation as shown in Scheme 3.

The outcome of exclusive cis-stereoselectivity in the Prins cyclization might be attributed to the most favorable conformation adopted by 12 with equatorial orientation of the 2,6-substituents $\left(\mathrm{R}^{1}\right.$ and $\left.\mathrm{R}^{2}\right)$. Alder and co-workers explained the formation of all-cis-2,4,6-trisubstituted THPs with the help of density functional theory (DFT) and stated that in the presence of an external nucleophile, the stabilization of the carbocation intermediate is favored through hyperconjugation [28]. The vacant p-orbital of C4 in TS 12a overlaps efficiently with the HOMO of the incoming nucleophile in an equatorial attack. Furthermore, this pseudoaxial C4 hydrogen atom in TS 12a leads to an optimal overlap between $\sigma$ and $\sigma^{*}$ of $\mathrm{C} 2-\mathrm{C} 3$ and $\mathrm{C} 5-\mathrm{C} 6$ with the coplanar equatorial lone pair of the oxygen atom and the empty p-orbital at $\mathrm{C} 4$. These orbital stabilizations, along with the lack of 1,3-diaxial interaction experienced by the incoming nucleophile (mostly halide) leads to the preferential equatorial attack over an axial attack by the nucleophile (Scheme 3 ) to give all-cis-2,4,6-trisubstituted THPs. In the absence of an external nucleophile, the successive proton loss leads to the formation of the 2,6-disubstituted dihydropyran. The regioselectivity of the Prins reaction is explained through the intermediates formed during the course of the reaction (Scheme 4). The $Z$-homoallylic alcohol reacts with an activated aldehyde to give oxocarbenium ion 15, wherefrom two competing transition states, 15a and 15b, can possibly form. In the 6-membered chair-like transition state $\mathbf{1 5 a}$, there is a 1,3-diaxial interaction between " $\mathrm{H}$ " and the substituent $\mathrm{R}^{2}$, while for the other fivemembered transition state $\mathbf{1 5 b}$, there is no such 1,3-diaxial interaction, which favors the formation of tetrahydrofuran product $\mathbf{1 7}$ instead of the tetrahydropyran $\mathbf{1 6}$ (Scheme 4).

Although the Prins cyclization is one of the powerful tools for the construction of 2,6-disubstituted THPs, there are some limitations that restrict a wide applicability. The major drawbacks identified with the Prins cyclization are the racemization due to competing oxonia-Cope rearrangement and sidechain exchange. Willis and co-workers studied the reactivity of the Prins reaction of different aryl group-substituted homoallylic alcohols 18 with propanal in the presence of a Lewis acid, which furnished the expected tetrahydropyran $\mathbf{2 3}$ as a single diastereomer via an oxocarbenium intermediate 21 (Scheme 5) $[29,30]$.

The reaction was dependent from the nature of the aromatic ring, which plays a crucial role in the product formation. Homoallylic alcohols with an electron-rich substituent at the arene ring produced predominantly symmetric THP product $\mathbf{2 6}$ over the desired trisubstituted heterocycle $\mathbf{2 3}$. The mechanism

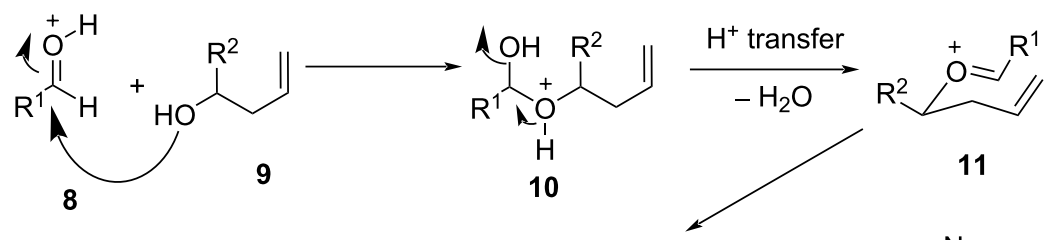

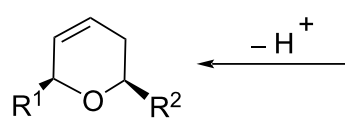

14<smiles>[R]C1C[CH+]C([R])C([R])O1</smiles>

12

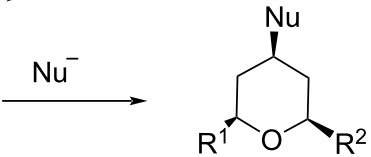

13

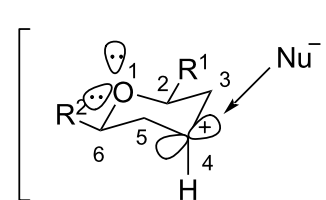

$12 a$

favored TS

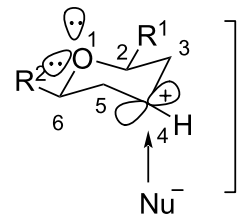

$12 b$

Scheme 3: General stereochemical outcome of the Prins cyclization. 


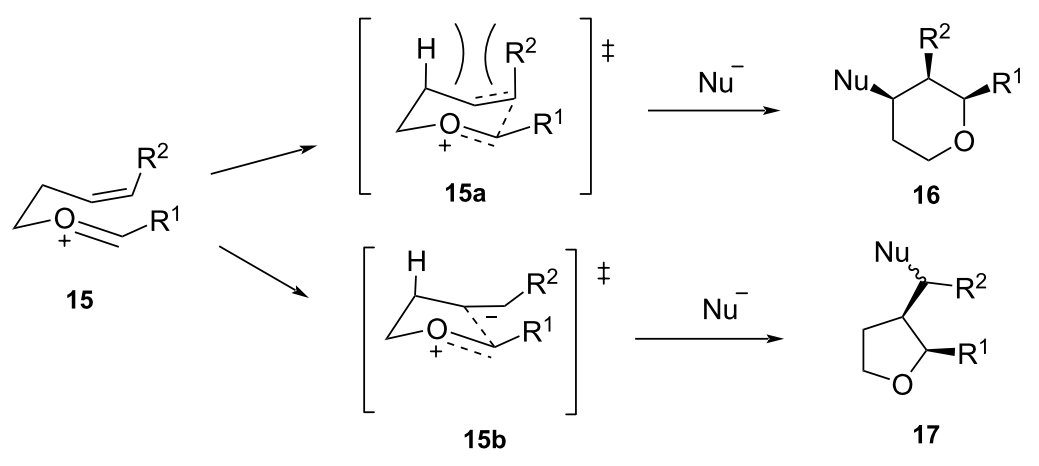

Scheme 4: Regioselectivity in the Prins cyclization.<smiles>C=CC[C+]c1ccc(OC)cc1</smiles><smiles>C=C=CCC</smiles>

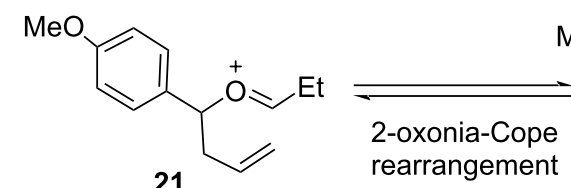

21<smiles>CCC1CC(OC(C)=O)C[C@@H](c2ccc(OC)cc2)O1</smiles><smiles>C=CCC(O)c1ccc(OC)cc1</smiles>

(S)-18<smiles>C=CCC(CC)O[O+]c1ccc(OC)cc1</smiles>

22<smiles>C=CCC(O)CC</smiles>

$\underset{\mathrm{EtCHO}, \mathrm{BF}_{3} \cdot \mathrm{OEt}_{2}}{\stackrel{\mathrm{AcOH}, \mathrm{TMSOAc}}{\longrightarrow}}$<smiles>CC[C@H]1C[C@@H](OC(C)=O)C[C@H](c2ccc(OC)cc2)O1</smiles>

Scheme 5: Mechanism of the oxonia-Cope reaction in the Prins cyclization.

of the reaction was further investigated using enantioenriched homoallylic alcohol $(S)$-18 with $89 \%$ ee, which favored 2-oxonia-Cope rearrangement to give THP 23 only in 14\% yield and $<5 \%$ ee. The poor enantiomeric excess of the product $\mathbf{2 3}$ indicates that the racemization takes place during the course of the reaction. It was explained that the reason for the loss of optical purity was due to the formation of a benzylic cation, which is stabilized by the electron-rich aromatic substituent. In contrast, the reaction with aromatic aldehydes equipped with the electron-deficient substituent produced the desired trisubstituted THP along with recovered starting material. The enantioenriched homoallylic alcohol bearing an electron-deficient substituent, 27 ( $94 \%$ ee), was investigated with propanal, which proceeded with high selectivity to give the corresponding THP 28 (79\% ee, 32\% yield) along with some recovered starting material (47\%), as shown in Scheme 6. 
<smiles>CCOCCOC(=O)C(C)(C)C=CCC(O)c1ccccc1Cl</smiles>

(S)-27

(94\% ee)<smiles>CCC1C[C@@H](OC(C)=O)C[C@@H](c2ccccc2Cl)O1</smiles>

$2 \%, 79 \%$ ee
(S)-27

$47 \%$

Scheme 6: Cyclization of electron-deficient enantioenriched alcohol 27.

Partial racemization was also reported at the same time by reversible 2-oxonia-Cope rearrangement and via side-chain exchange [31-33]. The racemization occurs during allyl transfer as a result of 2-oxonia-Cope rearrangement through a 3,3sigmatropic shift, which plays a crucial role during the reaction, as shown in Scheme 7.<smiles>C=CCC(O)c1ccccc1</smiles>

$$
\text { (S)-29 }
$$
$91 \%$ ee

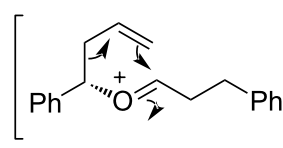
33 P cat.

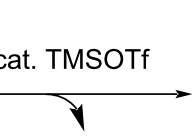
省 31<smiles>C=CCC(CCc1ccccc1)O[O+]c1ccccc1</smiles>
2-oxonium-Cope $\mathrm{Ph} P \mathrm{Ph}$ rearrangement
34
Scheme 7: Partial racemization through 2-oxonia-Cope allyl transfer.
The Prins cyclization between alcohol ( $R$ )-35 and aldehyde 36 was investigated under different Lewis acid conditions, as shown in Scheme 8 [33]. Cyclization promoted by $\mathrm{BF}_{3} \cdot \mathrm{OEt}_{2} /$ HOAc led to partial racemization of the desired product $\mathbf{3 7}$ (from $87 \%$ ee to $68 \%$ ee) and formation of side-chain exchange products 38 and 39 (symmetric tetrahydropyran). Presumably, this observation stands in support of the intervention of a 2-oxonia-Cope-mediated side-chain exchange reaction and is entirely consistent with Willis and co-workers' result [29], which leads to the partial racemization observed in the desired product formation. Another Lewis acid, $\mathrm{SnBr}_{4}$, was found to be more efficient than $\mathrm{BF}_{3} \cdot \mathrm{OEt}_{2} / \mathrm{HOAc}$ in terms of retention of enantiopurity in major product $\mathbf{3 7}$ during cyclization (from $87 \%$ ee to $85 \%$ ee, Scheme 8 ). This could probably be due to a faster rate of cyclization with $\mathrm{SnBr}_{4}$, which suppressed the competing 2-oxonia-Cope process.

In order to stop racemization during the Prins cyclization, a substrate in which an oxocarbenium ion is generated from a masked aldehyde bearing a homoallylic alcohol moiety has<smiles></smiles>

$$
\begin{aligned}
& \mathrm{O} \overbrace{\mathrm{Ph}} \\
& \text { TMSOAC }
\end{aligned}
$$$$
\mathrm{BF}_{3} \cdot \mathrm{OEt}_{2}, \mathrm{HOAc}
$$$$
\text { cylohexane, } 25^{\circ} \mathrm{C}
$$<smiles>C=CCC(O)c1ccccc1</smiles>

$(R)-35$

$87 \%$ ee

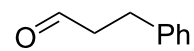

$\mathrm{SnBr}_{4}$ (2.2 equiv) $\mathrm{CH}_{2} \mathrm{Cl}_{2}$, -78 to $0^{\circ} \mathrm{C}$<smiles>CC(=O)O[C@@H]1C[C@@H](c2ccccc2)O[C@H](CCc2ccccc2)C1</smiles>

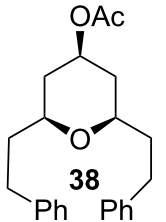<smiles>CC(=O)OC1CC(c2ccccc2)O[C@H](c2ccccc2)C1</smiles>

$+$<smiles>C=CCC(O)c1ccccc1</smiles>

$35,11 \%$ ee<smiles>O=C(O)CCCc1ccccc1</smiles><smiles>BrC1CC(c2ccccc2)OC(c2ccccc2)C1</smiles> 
been examined. In this context, the $\alpha$-acetoxy ethers with different functionalities at $\mathrm{C} 4$ were examined in the presence of a variety of Lewis acids, and it was found that the $\alpha$-acetoxy ether $(R)-42$ underwent Prins-type cyclization in the presence of $\mathrm{BF}_{3} \cdot \mathrm{OEt}_{2}$ as well as $\mathrm{SnBr}_{4}$ to deliver the desired $\mathbf{3 7}$ and $\mathbf{4 0}$, respectively, without loss of optical purity (Scheme 9) [34,35].

This strategy was successfully utilized for the synthesis of the natural product (-)-centrolobine [33] and for the stereoselective synthesis of the $\mathrm{C} 20-\mathrm{C} 27$ tetrahydropyran segment of phorboxazole A (Scheme 10) [36].

\section{Axial selectivity in the Prins cyclization}

To overcome the racemization process, the axially selective Prins cyclization was explored with a variety of substrates,

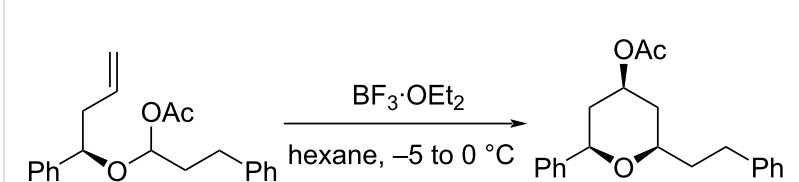

(R)-42

$87 \%$ ee

37 $72 \%, 87 \%$ ee

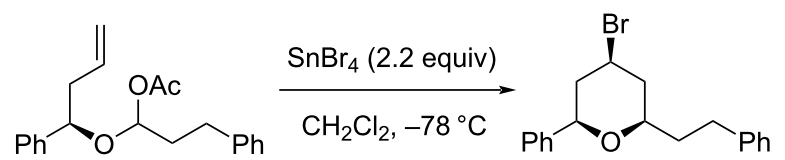

$(R)-42$

40

$72 \%, 87 \%$ ee

Scheme 9: Rychnovsky modification of the Prins cyclization.

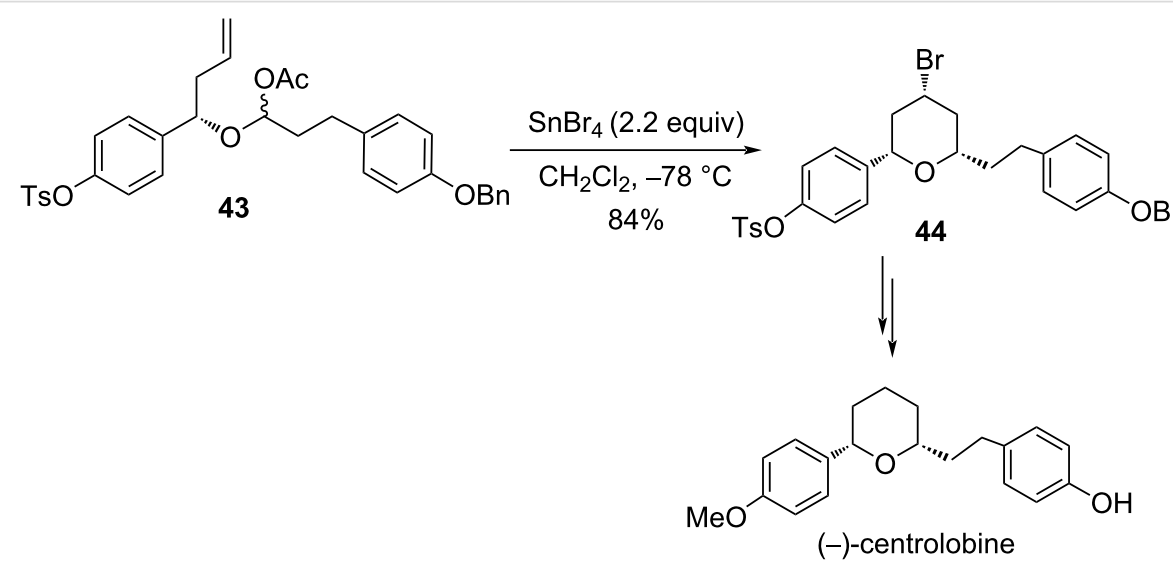<smiles>CC=CCC(CCO)OC(OC(C)=O)C(C)OCc1ccccc1</smiles>

45<smiles>CCO[Sb](=O)(O)CC(=O)O</smiles>

$140{ }^{\circ} \mathrm{C}$<smiles>[R]OCC[C@H]1O[C@H](C(C)OCc2ccccc2)C(C)[C@H](O)[C@H]1C(C)=O</smiles>

46

phorboxazole A

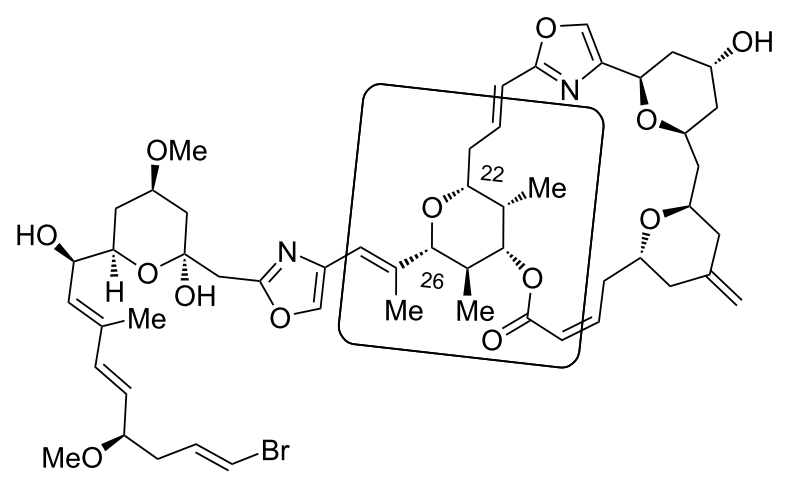

Scheme 10: Synthesis of (-)-centrolobine and the C22-C26 unit of phorboxazole A. 
which produced the corresponding THPs in excellent selectivity and good to excellent yield [37]. The experimental modification under segment coupling gave entirely the 4-axial product. For example, treatment of $\mathbf{4 7}$ with $\mathrm{SnBr}_{4}$ produced axial and equatorial products $\mathbf{4 8} \mathbf{a}$ and $\mathbf{4 8 b}$ in a 9:79 ratio under typical segment coupling. This selectivity was further improved for the formation of 48a by exclusively using $\mathrm{TMSBr}$ as a Lewis acid, as shown in Scheme 11.

The mechanistic rationale for an axially selective Prins cyclization is explained in Scheme 12 [38]. It is proposed that the reaction of 49 with $\mathrm{TMSBr}$ forms an intermediate 50, which, after solvolysis, affords an intimate ion pair $\mathbf{5 1}$. The proximal addition of a bromide ion to $\mathbf{5 1}$ produces axial adduct $\mathbf{5 6}$ exclusive- ly. However, when $\mathrm{SnBr}_{4}$ is used as a Lewis acid, oxocarbenium ion 52 is formed via 50. The counterion $\mathrm{SnBr}_{4}{ }^{-}$being much less nucleophilic than the $\mathrm{Br}^{-}$ion allows the formation of a solvent-separated ion pair $\mathbf{5 3}$, which results in the bromide addition to 53 preferentially from an equatorial position (Scheme 12).

\section{Mukaiyama aldol-Prins cyclization}

The Mukaiyama aldol-Prins (MAP) cyclization has also been explored for the synthesis of tetrahydropyran. In this approach, the side reaction is avoided by introducing a nucleophile into the enol ether, which traps the reactive oxocarbenium ion intermediate 60, leading to the formation of THP [39]. The first example of an MAP cascade reaction was reported by Rych-
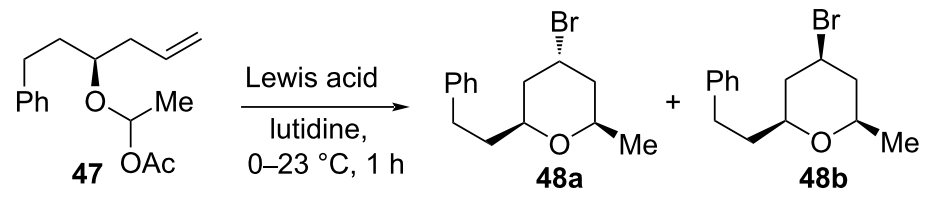

\begin{tabular}{l} 
Lewis acid \\
\hline $\mathrm{SnBr}_{4}$ \\
$\mathrm{TMSBr}$
\end{tabular}

$48 a$

$9 \%$

$98 \%$
$48 b$

$79 \%$

$0 \%$

Scheme 11: Axially selective Prins cyclization by Rychnovsky et al.<smiles>[R]C(CC=C)OC(C)OC(C)=O</smiles>

49

$\mathrm{R}=\mathrm{CH}_{2} \mathrm{CH}_{2} \mathrm{Ph}$<smiles>[R]C(C)C[C@H](C)CC(=O)OC</smiles>

53<smiles>[R]C(C)[C@@H](Br)CC([R])(C)C</smiles>

equitorial bromine<smiles>[R]C(CC=C)O[C@@H](C)Br</smiles>

50 $\mathrm{SnBr}_{4},-78^{\circ} \mathrm{C}$ $\mathrm{SnBr}_{5}$

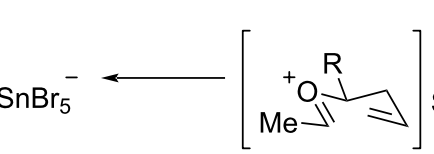

52

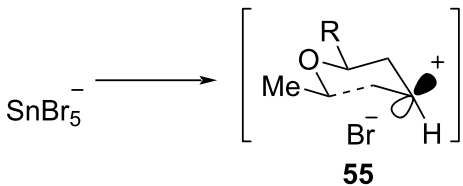

Scheme 12: Mechanism for the axially selectivity Prins cyclization. 
novsky and co-workers using allylsilane $\mathbf{6 2}$ as an internal nucleophile, as shown in Scheme 13 [40].

This approach was further extended to the synthesis of the macrolide lecasacandrolide $\mathrm{A}$ [41]. $\mathrm{BF}_{3} \cdot \mathrm{OEt}_{2}$ in combination with 2,6-di-tert-butylpyridine (DTBP) was a suitable combination for the synthesis of the THP unit of leucasacandrolide A, while $\mathrm{TiBr}_{4}$ [42] was found suitable in conjunction with DTBP for the synthesis of polyketide SCH 351448 [43], as shown in Scheme 14 .<smiles>[R]OC=C[B]</smiles><smiles>C=CO[C@@H](CCPc1ccccc1)CC(=C)C[As](C)(C)C</smiles>

Scheme 13: Mukaiyama aldol-Prins cyclization reaction.

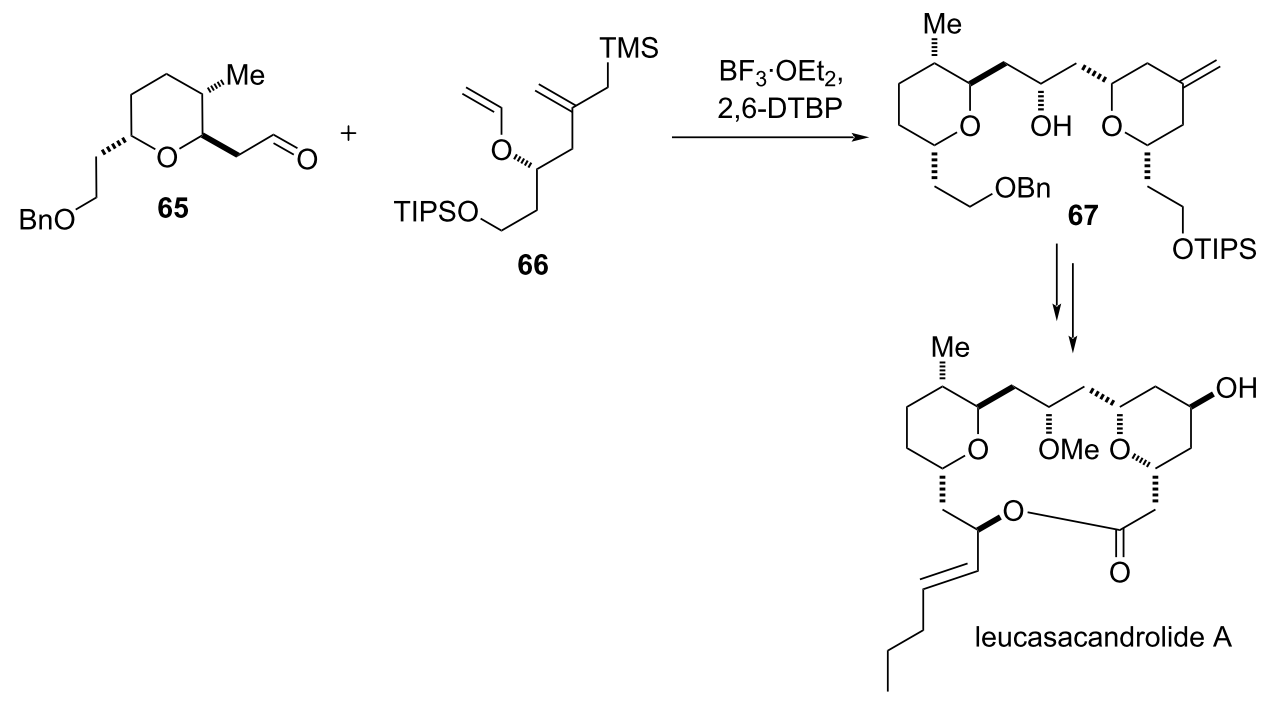<smiles>C=CCC(OC=C)C(C)(C)CCC(=C)C</smiles>

68
69

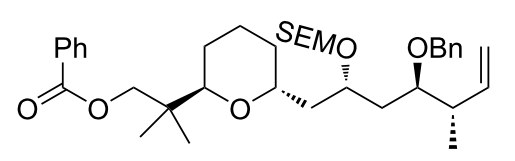

70 
Hart and Bennett have also examined the trifluroacetic acid-catalyzed Prins cyclization of acetal $\mathbf{7 1}$ to afford $\mathbf{7 2}$ along with side-chain-exchanged product 73 (Scheme 15) [44].

This method was utilized for the synthesis of (-)-blepharocalyxin D29 [45] and the macrolide leucascandrolide A [46]. In another type, the triflic acid-catalyzed Prins cyclization was used for the synthesis of 2,4,5,6-tetrasubstituted tetrahydropyran with complete control of stereochemistry, which is an important core of a variety of natural products, such as polycarvernoside A [47], clavoslide A [48], and (-)-blepharocalyxin $[49,50]$ and its analogs, as shown in Scheme 16.

Additionally, the reaction was used for the synthesis of rhoiptelol B, 7-desmethoxyfusarentin, and corresponding analogs [51]. Considering $\beta$-hydroxydioxinone as a better starting material for Prins cyclization, Scheidt and co-workers introduced a new method to access highly functionalized chiral THP efficiently (Scheme 17) [52].

Furthermore, the possible reaction pathway indicates the formation of oxocarbenium ion $\mathbf{8 2}$, followed by $\mathrm{C}-\mathrm{C}$ bond formation via a chair-like transition state to afford $\mathbf{8 3}$ (Scheme 18). A se- quence of reactions involving elimination of a proton from $\mathbf{8 3}$, treatment of 84 with an alkoxide, and protonation of the resulting enolate delivered thermodynamically favored equatorial ester $\mathbf{8 0}$ and $\mathbf{8 1}$.

The highly diastereoselective Brønsted superacid-catalyzed Prins cyclization of unsaturated enol ether 85 to cis-2,6disubstituted 4-methylenetetrahydropyran $\mathbf{8 6}$ (55\% yield) as shown in Scheme 19 was reported by Hoveyda and co-workers [53].

Funk and Cossey demonstrated that ene-carbamate could be an excellent terminating group for Prins cyclization [54]. The reaction involved 87 in the presence of the mild Lewis acid $\mathrm{InCl}_{3}$ and benzaldehyde (88), which produced all-cis-tetrahydropyran4-one 90 in excellent yield. The transformation proceeded through cyclization of a diequatorial chair-like conformation of the oxocarbenium ion $\mathbf{8 9}$ to provide an $N$-acyliminium ion, which upon hydrolysis produced $\mathbf{9 0}$. Similarly, the reaction of 91 produced all-cis-2,3,6-trisubstituted tetrahydropyran 93 . The application of this reaction was further extended by an exceptionally concise formal total synthesis of the nuclear export inhibitor (+)-ratjadone A, as shown in Scheme 20.

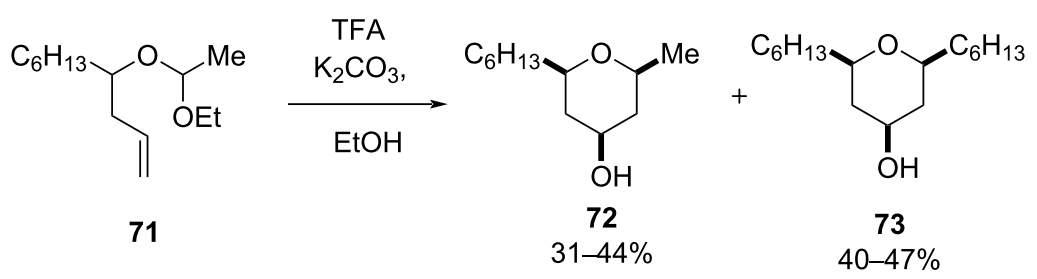

Scheme 15: Hart and Bennet's acid-promoted Prins cyclization.

(-) clavoslides A and D

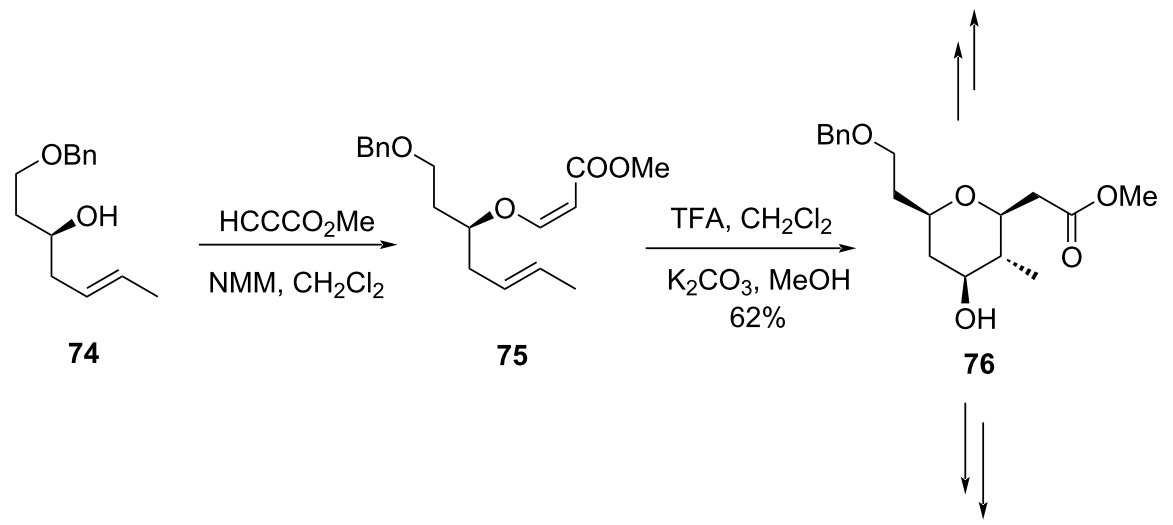

polycarvernoside $\mathrm{A}$ 

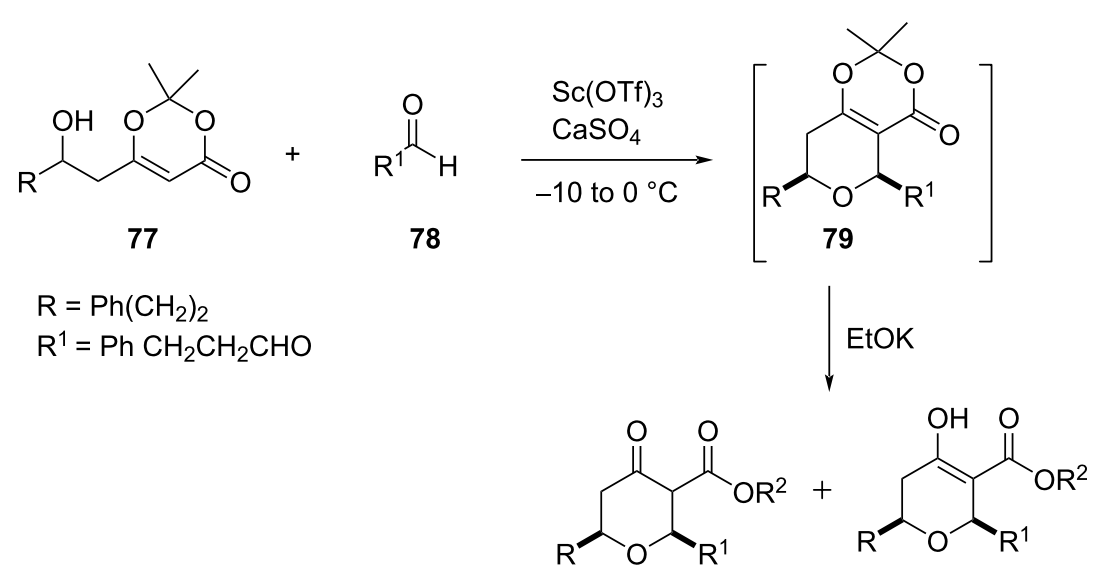

80

$78 \%$, dr $95: 5$

keto/enol 4:1

Scheme 17: Scheidt and co-workers' route to tetrahydropyran-4-one.

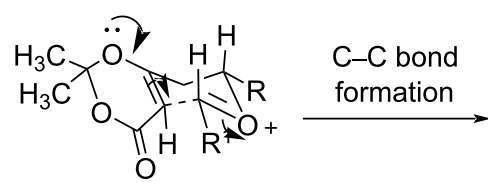

82

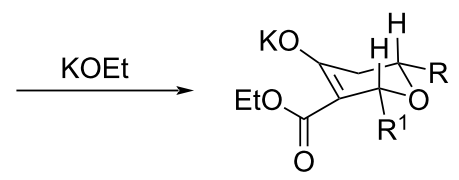

81

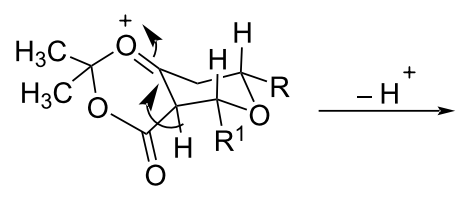

83

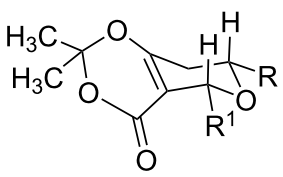

84<smiles>C=COC(CC(=C)C)C1CCCCC1</smiles>

85

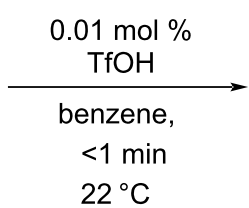

$22{ }^{\circ} \mathrm{C}$

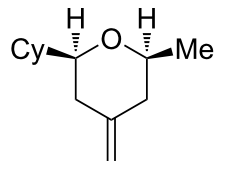

86

$55 \%, d r>98 \%$
Scheme 19: Hoveyda and co-workers' strategy for 2,6-disubstituted 4-methylenetetrahydropyran.

Stereoselective Prins cyclization of substituted cyclopropylcarbinol 94 to 2,4,6-trisubstituted tetrahydropyran 97 was reported by Yadav and Kumar [55]. In this reaction, a homoallylic cation was generated from 94 by the opening of the cyclopropane ring in the presence of TFA, which upon reacting with an aldehyde delivered 2,4,6-trisubstituted tetrahydropyran 97 through Prins cyclization, as shown in Scheme 21.
Similarly, an $\mathrm{SnCl}_{4}$-catalyzed Prins reaction was reported for the synthesis of 4-chlorotetrahydropyran 100. This intermediate was further utilized for the synthesis of the natural product centrolobine, as shown in Scheme 22 [56].

A strategy involving $\mathrm{BiCl}_{3}$-catalyzed microwave-assisted Prins cyclization of homoallylic alcohol $\mathbf{1 0 1}$ with an aldehyde $\mathbf{1 0 2}$ was successfully employed for the synthesis of 4-chloro-cis-2,6disubstituted tetrahydropyran $\mathbf{1 0 3}$ as a single diastereomer [57], as shown in Scheme 23.

In continuation, 4-amidotetrahydropyran derivative 106 was also synthesized from homoallylic alcohol $\mathbf{1 0 4}$ and an aldehyde 105 using a combination of cerium chloride and acetyl chloride following a Prins-Ritter reaction sequence (Scheme 24) [58]. $10 \mathrm{~mol} \%$ cerium chloride was used as a reaction promotor, which dramatically improved the reaction rate and yield of the reaction. 


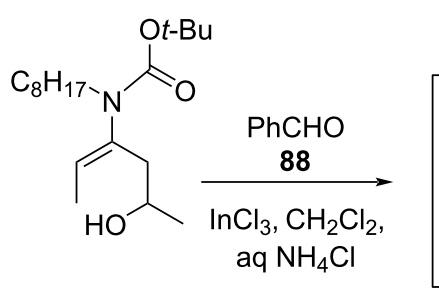

87

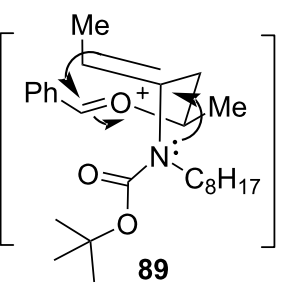

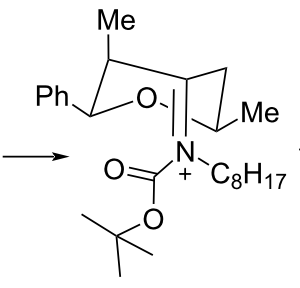<smiles>CC(=O)C(C)C(C)C(C)C(=O)O</smiles>

90

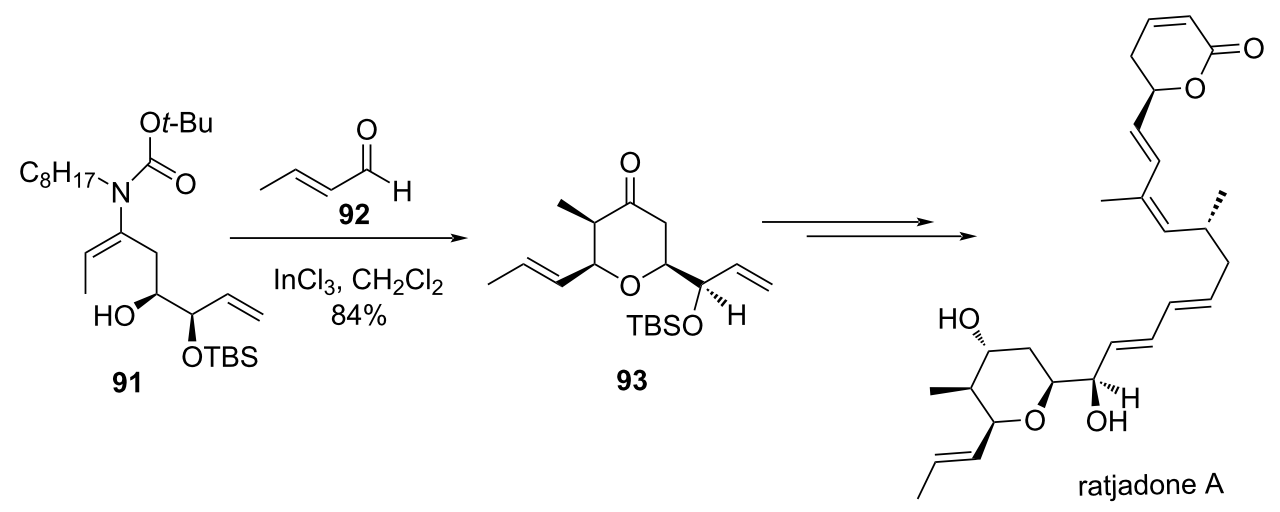

Scheme 20: Funk and Cossey's ene-carbamates strategy.

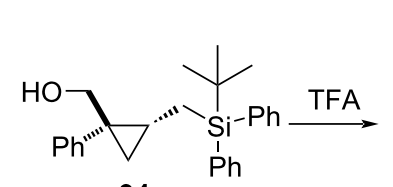

94

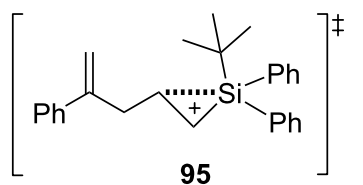

$\mathrm{R}-\mathrm{CHO}$

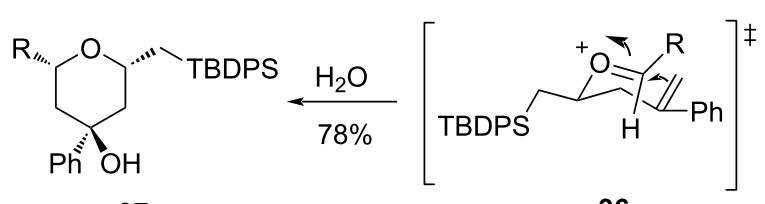

97

Scheme 21: Yadav and Kumar's cyclopropane strategy for THP synthesis.

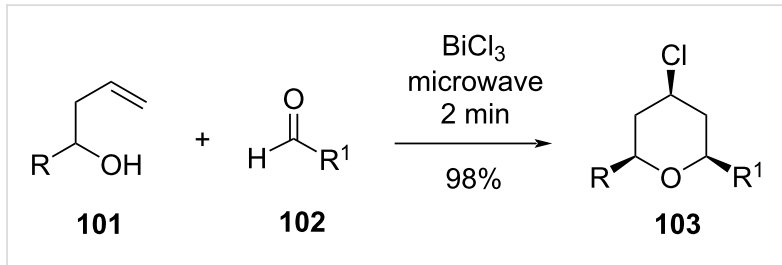

$R=R^{1}=1,2$-dichlorobenzene

Scheme 23: Yadav and co-workers' strategy for the synthesis of THP.

In a related study, the synthesis of polysubstituted tetrahydropyrans was described by Amberlyst ${ }^{\circledR}$ 15-catalyzed cyclization of homoallyl alcohol $\mathbf{1 0 7}$ and aldehydes 108. This method was further employed for the synthesis of highly substituted tetrahydropyrans with three contiguous stereocenters in one single operation [59]. The utility of this approach is showcased in the enantioselective total synthesis of (+)-prelactones B, C, and V, as shown in Scheme 25.<smiles>COc1ccc(C2CC2CO)cc1</smiles>

98<smiles>O=CCCc1ccc(OCc2ccccc2)cc1</smiles>

99<smiles>CC#CCCC</smiles>

( \pm -centrolobine 
<smiles>C=CCC(O)C1CCCCC1</smiles>

Scheme 24: Yadav and co-workers' Prins-Ritter reaction sequence for 4-amidotetrahydropyran.

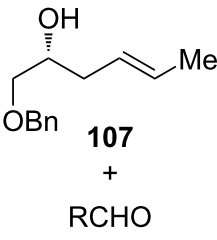

108

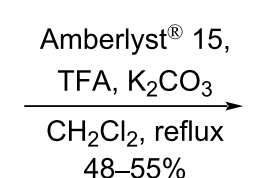
$48-55 \%$<smiles>CC(C)C1OC(=O)CC(O)C1C</smiles><smiles>[R]C1O[C@H](COc2ccccc2)CC(O)C1C</smiles>

109<smiles>CC1OC(=O)C[C@@H](O)[C@@H]1C</smiles>

prelactone $\mathrm{V}$<smiles>C=CC#CC(=O)OC1OC(=O)C[C@@H](O)[C@@H]1C=CC</smiles>

Scheme 25: Yadav and co-workers' strategy to prelactones B, C, and V.

Yadav's group reported the synthesis of 4-iodotetrahydropyrans $(\mathrm{dr}=7.5: 2.5)$ from aromatic aldehyde 111 and homoallylic alcohol 110 using TMSCl and NaI. Furthermore, the major diastereomer was utilized for the synthesis of centrolobine, as shown in Scheme 26 [60].

Loh and co-workers have shown the construction of cis-2,6disubstituted tetrahydropyran $\mathbf{1 1 6}$ with an exocyclic double bond by reacting homoallylic alcohol 114 and aldehyde $\mathbf{1 1 5}$ in the presence of a catalytic amount of $\operatorname{In}(\mathrm{OTf})_{3}$ [61]. This approach was further used for the synthesis of a common intermediate 117 for (-)-zampanolide and (+)-dactyloide (Scheme 27) [62].

Further improvement of this reaction was achieved by carrying out the Prins cyclization between homoallyl alcohol 118 (or<smiles>C=CCC(O)CCc1ccc(O)cc1</smiles>

( \pm )-centrolobine 


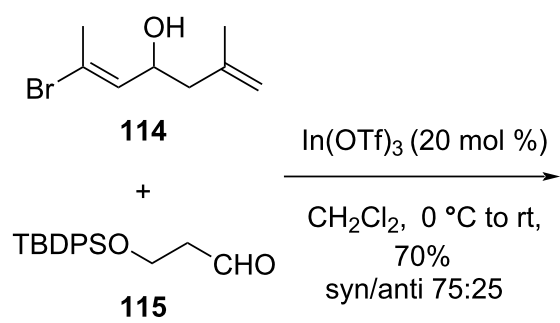<smiles>CC(Br)=CC1CC(=[18O])CC(CCO[Pb])O1</smiles>

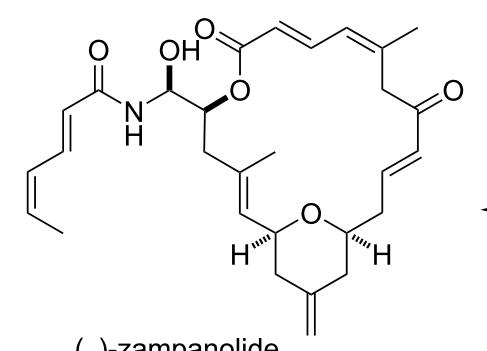

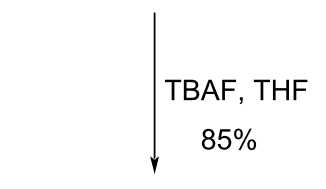

(-)-zampanolide<smiles>C=C1CCOC(/C=C(\C)CC(C=O)OC(=O)/C=C/C=C(/C)CC(=O)/C=C/C)C1</smiles><smiles>C=C1CC(/C=C(\C)Br)O[C@@H](CCO)C1</smiles>

(+)-dactyloide

Scheme 27: Loh and co-workers' strategy for the synthesis of zampanolide and dactylolide.

using the corresponding aldehyde and allylsilyl chloride 119) and an aldehyde $\mathbf{1 2 0}$ in the presence of a catalytic amount of the mild Lewis acid $\operatorname{In}(\mathrm{OTf})_{3}$ and trimethylsilyl halide as an additive to produce cis-4-halo-2,6-disubstituted tetrahydropyran $\mathbf{1 2 1}$ (Scheme 28) [63,64]. It was noticed that the problem associated with epimerization of the substrate has been successfully overcome in this reaction, which was demonstrated in the enantioselective total synthesis of (-)-centrolobine using catalytic $\mathrm{InBr}_{3}$ as a mild Lewis acid.
This strategy was further explored to construct tetrasubstituted cis-2,6-disubstituted 4,5-dibromotetrahydropyran $\mathbf{1 2 4}$ with high stereoselectivity using $\gamma$-brominated homoallylic alcohol (Z)-122 and aldehyde $\mathbf{1 2 3}$ in the presence of $\mathrm{InBr}_{3}$ and $\mathrm{TMSBr}$ in $\mathrm{CH}_{2} \mathrm{Cl}_{2}$ at $0{ }^{\circ} \mathrm{C}$ (Scheme 29) [65].

Metzger and co-workers reported an $\mathrm{AlCl}_{3}$-catalyzed cyclization of methyl ricinoleate (127) with various aldehydes to produce 2,3,6-trialkyl-substituted 4-chlorotetrahydropyran 128<smiles>[Y]C1CC([Y])OC(CCc2ccccc2)C1</smiles> 


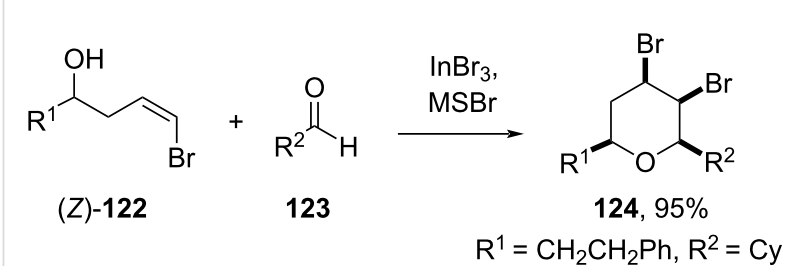

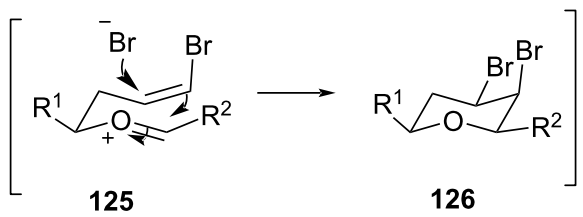

Scheme 29: Prins cyclization of cyclohexanecarboxaldehyde.

with excellent stereocontrol in all-cis-configuration (Scheme 30) [66].

The stereochemical outcome of this cyclization was rationalized by a chair-like transition state to produce predominantly the all-cis product. Similarly, cis- and trans-129 (1:4), generated in situ from methyl 10-undecenoate and an aldehyde $\mathbf{1 3 0}$ via ene reaction, undergo cyclization to form THPs 131 and 132 (Scheme 31).

Martín and co-workers reported a general strategy based on a reaction sequence of Evans aldol addition to construct a homoallylic alcohol, followed by Prins cyclization to furnish 2,3,4,5,6-pentasubstituted tetrahydropyrans 137 using $\beta, \gamma$-unsat- urated $N$-acyloxazolidin-2-ones $\mathbf{1 3 4}$ as a key precursor [67]. In this Evans aldol-Prins (EAP) protocol, four new $\sigma$-bonds and five contiguous stereocenters were generated as shown in Scheme 32 .

\section{Silyl-Prins cyclization}

Extensive research efforts were made towards the synthesis of THP using the silyl-Prins cyclization reaction. In this reaction, an oxocarbenium ion is being trapped by allylsilanes, vinylsilanes, alkenyl methylsilanes, or propargylsilanes to produce a variety of the Prins-cyclized products. The allyl metalation, followed by intramolecular Sakurai cyclization (IMSC) provides an efficient route to a variety of tetrahydropyran derivatives, as described by Marko and Leroy [68,69]. In these approaches, an initial ene reaction between an aldehyde $\mathbf{1 3 9}$ and the allylsilane 138 was promoted by $\mathrm{Et}_{2} \mathrm{AlCl}$ to generate $Z$-configured homoallylic alcohol 140. Condensation of 140 with another aldehyde in the presence of $\mathrm{BF}_{3} \cdot \mathrm{OEt}_{2}$ afforded the polysubstituted exo-methylene tetrahydropyran $\mathbf{1 4 2}$ in a completely stereocontrolled manner. The reaction proceeded via oxocarbenium 141, which upon intramolecular trapping by the allylsilane moiety through a chair-like transition state delivers the product (Scheme 33) [68].

An analogous reaction was reported between $(E)$-enol carbamate 143 and an aldehyde 144 in the presence of $\mathrm{BF}_{3} \cdot \mathrm{OEt}_{2}$ to provide THP 146 with exquisite diastereoselectivity. The carbamate substituent adopted the axial disposition in the proposed transition state 145, as shown in Scheme 34 [69].

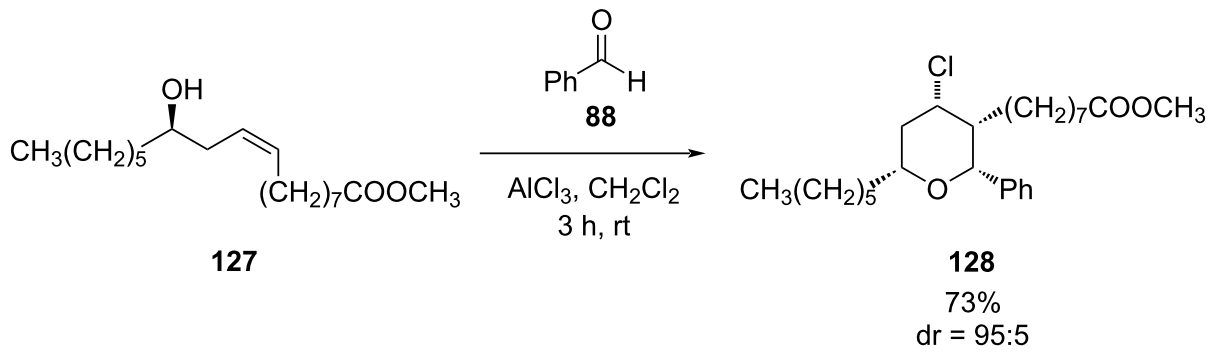

Scheme 30: Prins cyclization of methyl ricinoleate (127) and benzaldehyde (88).<smiles>[R]C(O)C/C=C\C=C(C)OC</smiles>

cis-129<smiles>[R]C(O)CC=CCC(C)=O</smiles>

trans-129

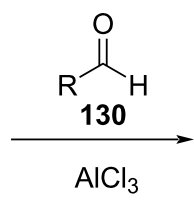<smiles>[R]C1CC(Cl)C(C=CC(=O)OC)C([R])O1</smiles>

major/minor 2.6:1 
<smiles>[R]C=CCC(=O)N1CCOC1=O</smiles><smiles>[R]C=C[C@H](C(=O)N1CCOC1=O)C([R])O</smiles>

134

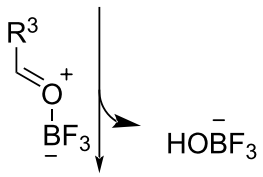<smiles>[R]C=C[C@@H](C(=O)N1CCOC1=O)C([R2])[O+]=C[R]</smiles>

i) TEA, $n-\mathrm{Bu}_{2} \mathrm{BOTf}$, $\mathrm{CH}_{2} \mathrm{Cl}_{2},-78^{\circ} \mathrm{C}, 30 \mathrm{~min}$

ii) $0{ }^{\circ} \mathrm{C}, 20 \mathrm{~min}$, then, $-78{ }^{\circ} \mathrm{C}$

iii) $\mathrm{R}^{2} \mathrm{CHO},-78^{\circ} \mathrm{C}$ to $\mathrm{rt}, 15 \mathrm{~h}$<smiles>[R]C=C[C@H](C(=O)N1CCOC1=O)C([R])O</smiles>

134

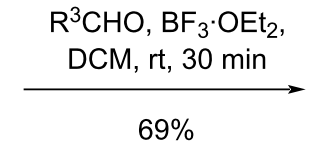

mechanistic cycle

$$
\begin{gathered}
R^{1}=\mathrm{Et} \\
\mathrm{R}^{2}=\mathrm{iBu} \\
\mathrm{R}^{3}=\mathrm{iBu}
\end{gathered}
$$<smiles>[R]C1OC([R])C2C(=O)N(CCO)C(=O)OC2C1[R]</smiles><smiles>CCC</smiles>

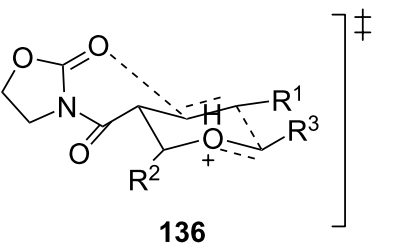

136

Scheme 32: Martín and co-workers' stereoselective approach for the synthesis of highly substituted tetrahydropyrans through an Evans aldol-Prins cyclization strategy.
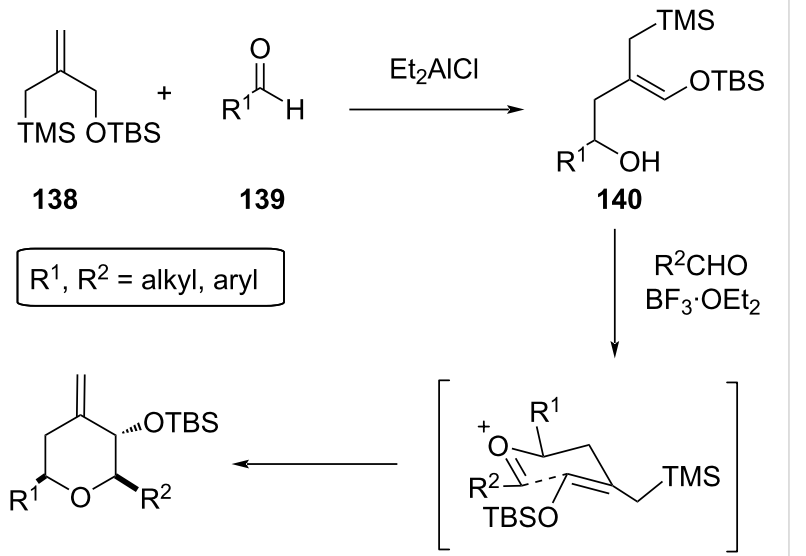

$142,63-77 \%$

141

Scheme 33: Ene-IMSC strategy by Marko and Leroy for the synthesis of tetrahydropyran.

In another report by Rychnovsky and Gisinsky, two of the tetrahydropyran rings of the potent molluscicide cyanolide A were synthesized via a silyl-Prins cyclization and Sakurai macrocyclization/dimerization strategy to produce $\mathbf{1 5 0}$ in the presence of TMSOTf, as shown in Scheme 35 [70].

Hoye and Hu utilized camphor sulfonic acid (CSA) to construct a cis-2,6-disubstituted tetrahydropyran 153 via an intramolecular Sakurai cyclization reaction between the enal $\mathbf{1 5 1}$ and an allylisilane 152. Further manipulation of functional groups of 153 leads to the synthesis of (-)-dactyloide (Scheme 36) [71].

The one-pot synthesis of a 2,6-disubstituted THP was reported by Minehan and co-workers and involved treating 3-iodo-2[(trimethylsilyl)methyl]propene with an aldehyde in the presence of indium metal to produce homoallylic alcohol 156 (Scheme 37), which underwent a silyl-Prins cyclization to form polysubstituted exo-methylene THPs 157 [72].

\section{Tandem allylation-silyl-Prins cyclization}

Tetrahydropyran can also be synthesized stereoselectively by sequential allylation to an aldehyde, followed by silyl-Prins cyclization of the resulting homoallylic alcohol. For illustration, a facile enantioselective strategy for the synthesis of cis-2,6-disubstituted 4-methylenetetrahydropyran 161 (91\% yield, $\mathrm{dr}=5: 1)$ was reported by $\mathrm{Yu}$ et al, utilizing, first, asymmetric allylation of an aldehyde by using [ $\{(R)-$ BINOL $\left.\} \mathrm{Ti}(\mathrm{IV})\left\{\mathrm{OCH}\left(\mathrm{CF}_{3}\right)_{2}\right\}_{2}\right]$ as a chiral promotor in $\mathrm{PhCF}_{3}$, followed by cyclization using $\mathrm{R}_{2} \mathrm{CHCl}(\mathrm{OMe})$ in the presence of TMSNTf $_{2}$, as shown in Scheme 38 [73]. The internal chirality transfer during cyclization probably took place due to the geometrical preference of $\mathbf{1 6 2}$ to minimize the allylic strain with the existing stereogenic center (pseudoaxial group), leading to the formation of cis-tetrahydropyran $\mathbf{1 6 1}$ rather than a transtetrahydropyran. 
<smiles>[R]C(O)C/C(=C\OOCC)CO[Na]</smiles>

143

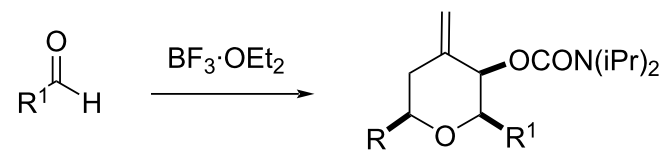

$146,78-91 \%$

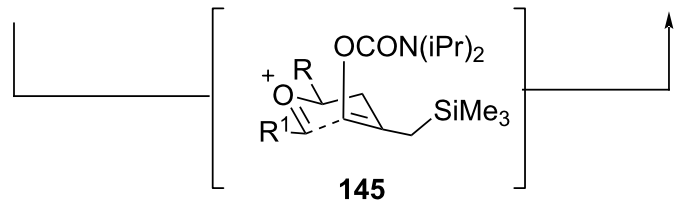

Scheme 34: Marko and Leroy's strategy for the synthesis of tetrahydropyrans 146.
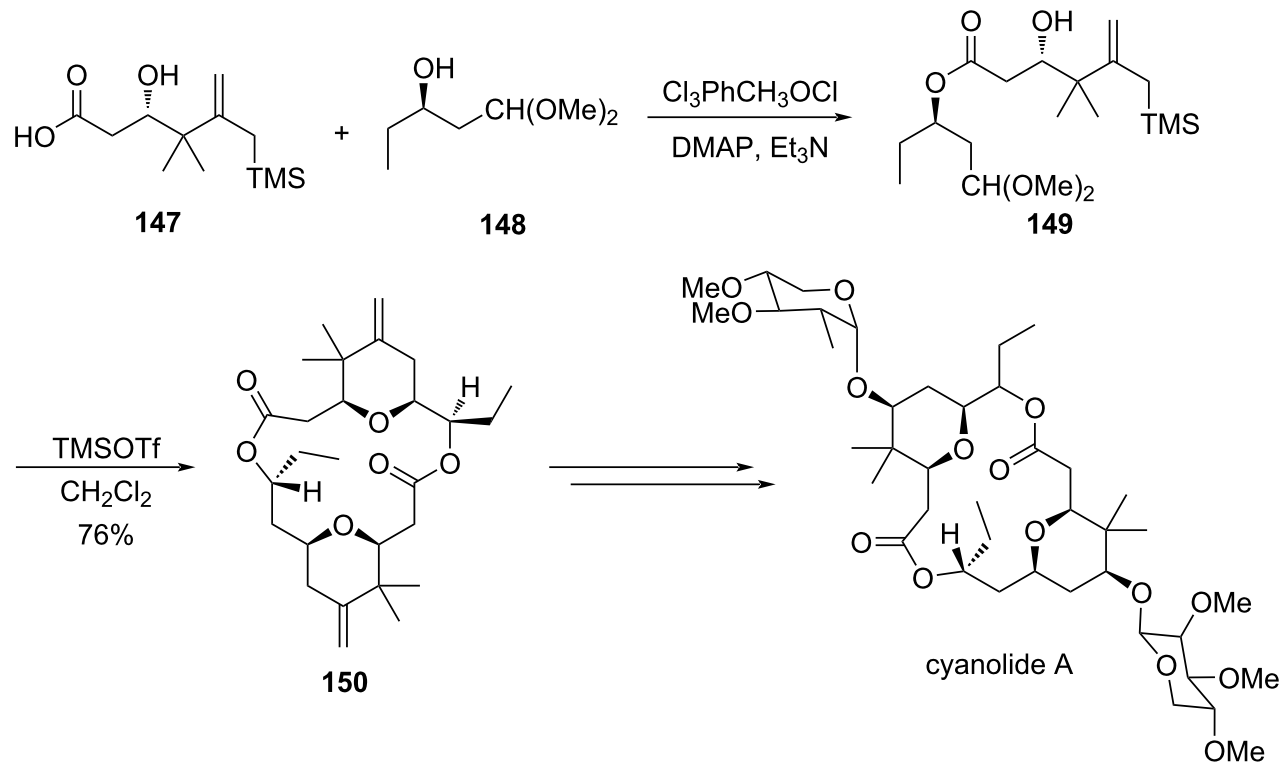

Scheme 35: Sakurai dimerization/macrolactonization reaction for the synthesis of cyanolide A

Floreancig and co-workers utilized a tandem allylation-silylPrins cyclization strategy to afford 2,6-disubstituted tetrahydropyran 167 by ionizing $\alpha, \beta$-unsaturated acetals 164 in the presence of electron-rich olefins using $\mathrm{Ce}\left(\mathrm{NO}_{3}\right)_{3}$ and SDS in water [74]. The mechanism of the reaction is shown in Scheme 39, which plausibly proceeded through trapping of oxocarbenium ion $\mathbf{1 6 6}$ in a chair-like transition state.

The stability of the acetal under these reaction conditions reflected that the acid-sensitive functional groups are well tolerated in the cyclized product. Furthermore, a natural product, (+)-dactyloide, was synthesized by following the above strategy using an appropriate acetal (Scheme 40) [75].

The synthesis of enantiomerically enriched 172, cis-2,6-DHP and trans-2,6-DHP, respectively, was reported by a $[4+2]$-annulation strategy. The authors utilized crotylsilanes syn-170 and anti-170, respectively, with an aldehyde $\mathbf{1 7 1}$ in the presence of TMSOTf to deliver different DHPs 172 (Scheme 41) [76].

For syn-170, the reaction went via the favored boat-like transition state $\mathbf{1 7 3}$ instead of the disfavored chair-like transition state $\mathbf{1 7 4}$ to cis,trans-175 as a product (Scheme 42).

In contrast, the reaction of anti-170 proceeded, however, through similar boat-like transition states $\mathbf{1 7 6}$ and $\mathbf{1 7 7}$ where the interaction between the methyl substituent and the alkyl group of aldehyde was less, leading to the formation of trans,trans $\mathbf{- 1 7 8}$ as a major product, as shown below in Scheme 43.

A variety of natural products, such as (-)-apicularen A [77], the C1-C13 fragment of bistramide A71 [78], herboxideiene/ 


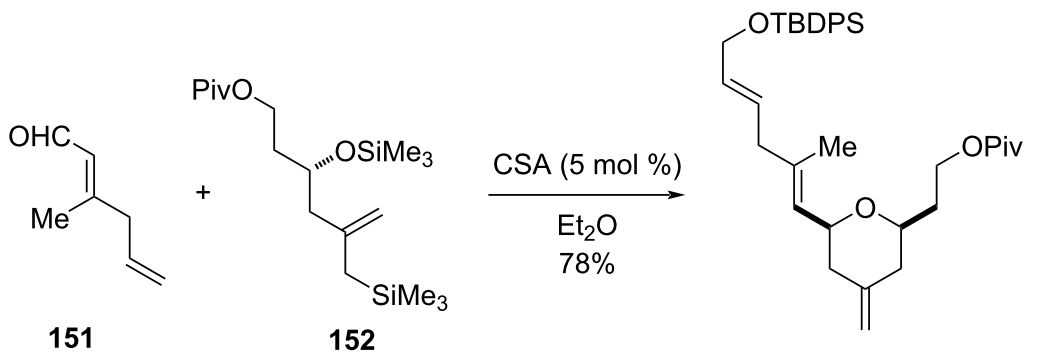

153

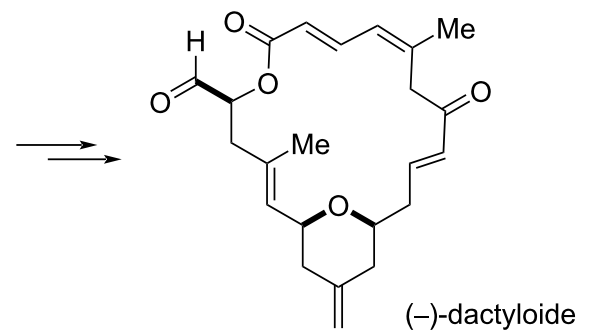

Scheme 36: Hoye and Hu's synthesis of (-)-dactyloide by intramolecular Sakurai cyclization.

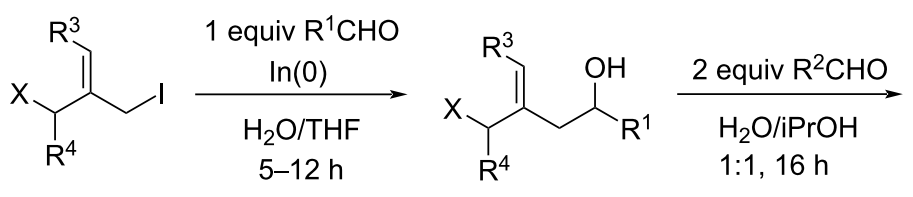

154; $X=\mathrm{SiMe}_{3}, \mathrm{R}^{3}, \mathrm{R}^{4}=\mathrm{H}$

155; $X=H, R^{3}, R^{4}=-\left(\mathrm{CH}_{2}\right)_{3}-$
156<smiles>[R]C=C1CC([R])OC([R])[C@H]1[R]</smiles>

157

$42-83 \%$

Scheme 37: Minehan and co-workers' strategy for the synthesis of THPs 157.

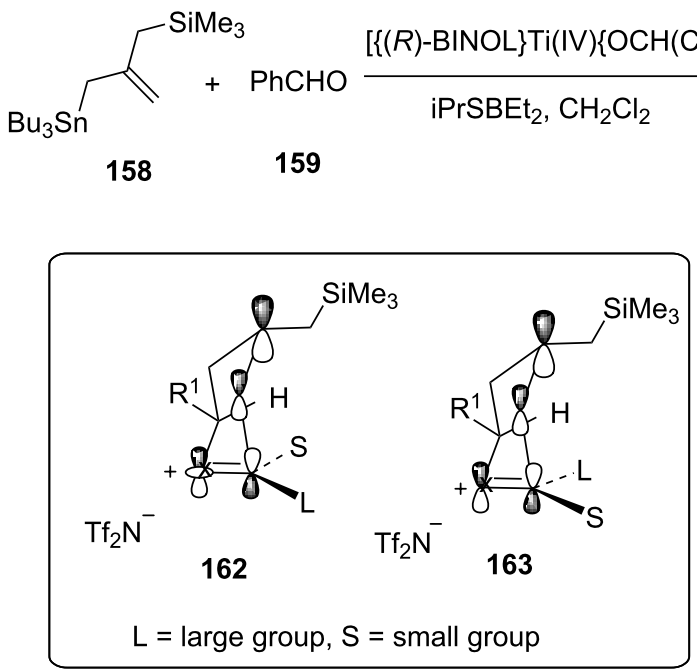<smiles>C=C(C[C@H](C)c1ccccc1)C[C@H](O)c1ccccc1</smiles>

160

1. $\mathrm{R}^{2} \mathrm{CHCl}(\mathrm{OMe})$, $\mathrm{iPrNEt}_{2}$ $\mathrm{CH}_{2} \mathrm{Cl}_{2},-78^{\circ} \mathrm{C}$ 2. $\mathrm{TMSNTf}_{2}$

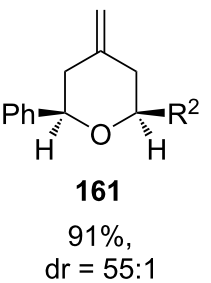

Scheme 38: Yu and co-workers' allylic transfer strategy for the construction of tetrahydropyran 161. 
<smiles>C=C(C[AsH2])CC1CCOC(/C=C/C)O1</smiles>

164

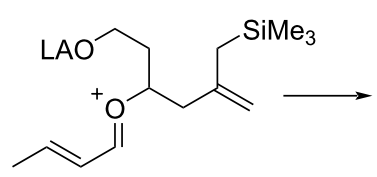

165

LA $=$ Lewis acid

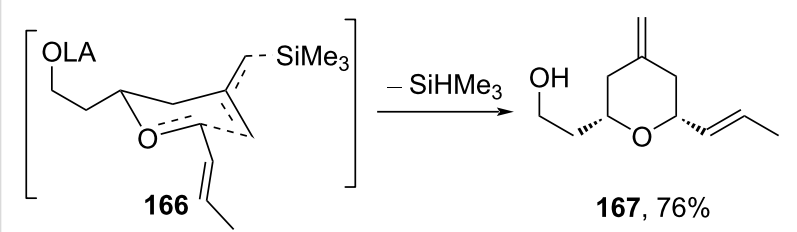

Scheme 39: Reactivity enhancement in intramolecular Prins cyclization.

GEX1A [79], (+)-kendomycin [80], and (+)-SCH351448 [81] were synthesized utilizing this $[4+2]$-annulation strategy. Following the above annulation route, later, Roush's group Introduced $\beta$-hydroxyallylsilanes for the synthesis of 2,6-disubstituted DHP (Scheme 44) [82].

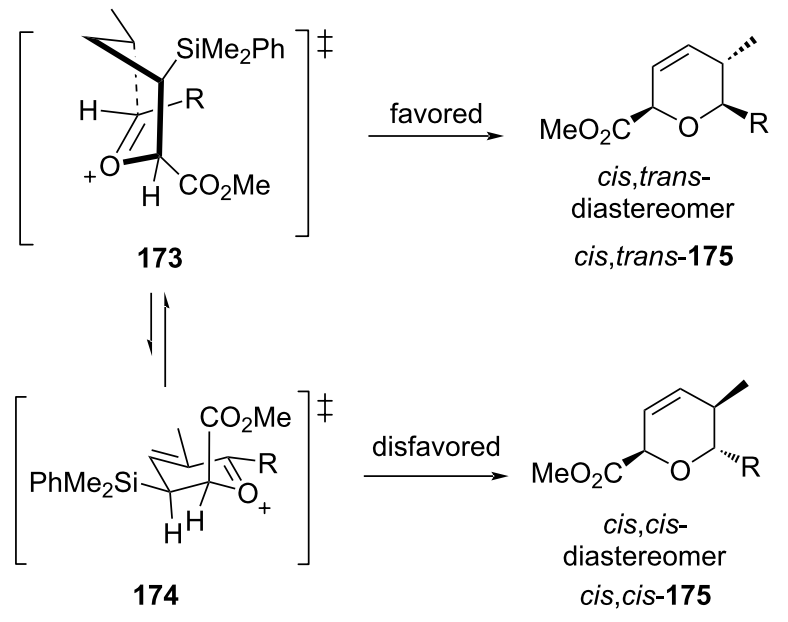

Scheme 42: Panek and Huang's DHP synthesis from syn-crotylsilanes.

This strategy was further utilized for the synthesis of the C29-C45 bispyran subunit (E-F) of spongistatin [82]. 2,6Disubstituted 4-methylenetetrahydropyran was also synthesized from silylstannane and two units of aldehyde in a two-step protocol. The first step involves the addition between silylstan-

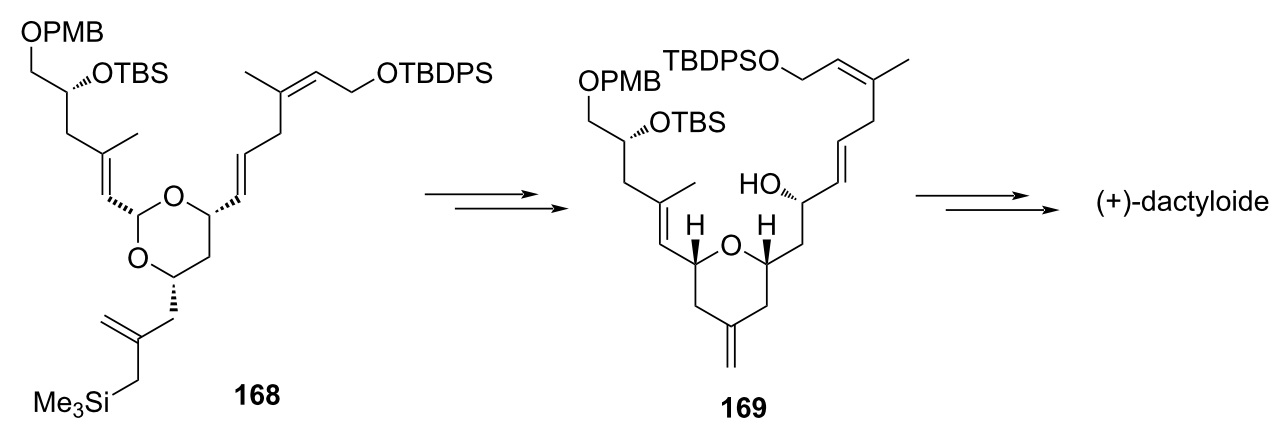

Scheme 40: Floreancig and co-workers' Prins cyclization strategy to (+)-dactyloide.
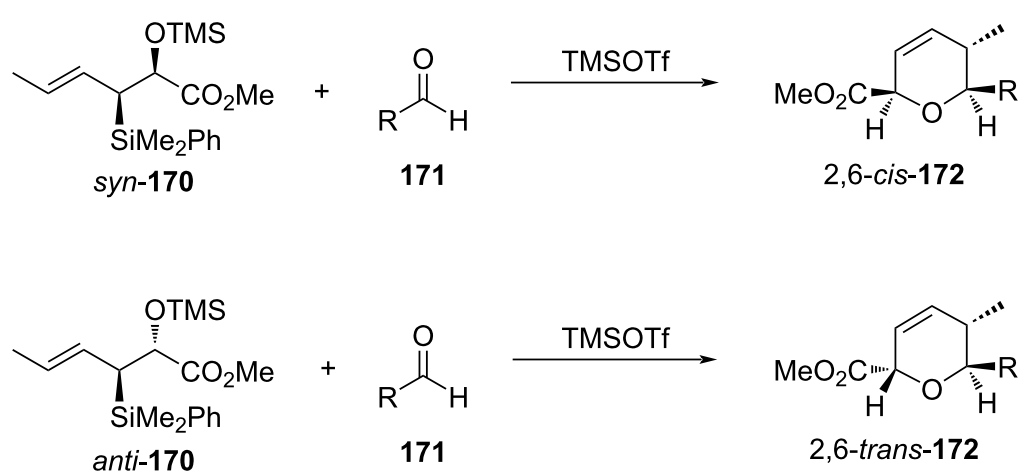


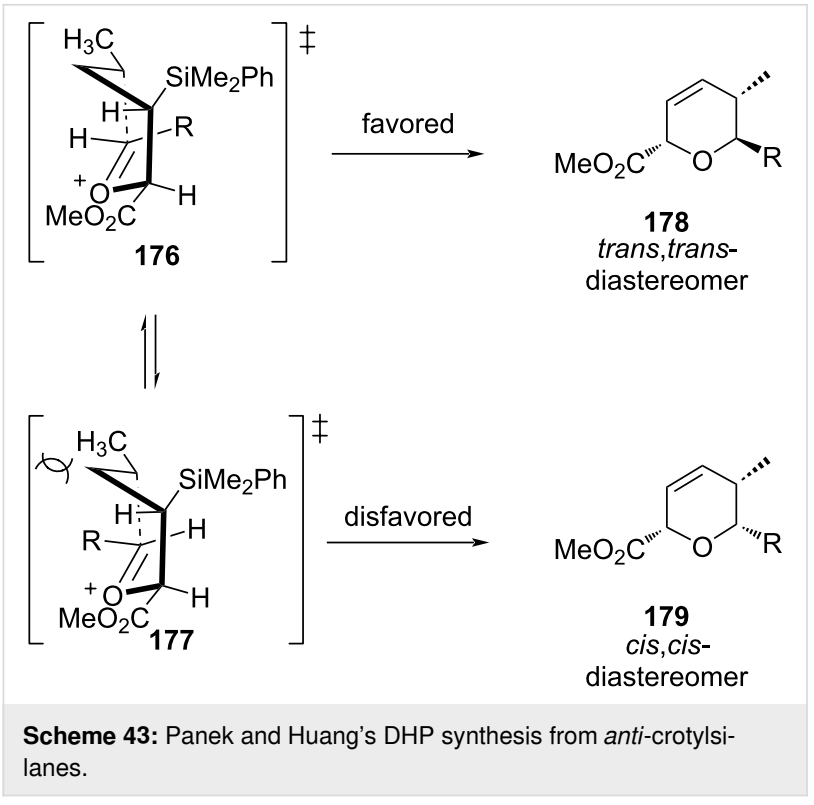

nane $\mathbf{1 8 5}$ and an aldehyde in the presence of titanium BINOLate as a catalyst, which afforded hydroxyallylsilane $\mathbf{1 8 6}$ with excellent enantioselectivity (Scheme 45) [83-85]. This, upon further reaction with another aldehyde in the presence of TMSOTf, gave 2,6-disubstituted 4-methylenetetrahydropyran $\mathbf{1 8 7}$. This strategy was utilized for the synthesis of bryostatin and (+)-dactyloide analogs [86-88].

Similar to Prins cyclization of allylsilanes, Dobbs and co-workers recently utilized the corresponding vinylsilane as an alternative for the synthesis of cis-2,6-dihydropyran [89,90]. The synthesis involves tandem addition of vinylsilane, followed by silyl-Prins cyclization reaction. For example, 4-trimethylsilylpent-4-en-2-ol (188), upon reaction with phenylacetaldehyde (189) in the presence of $\mathrm{InCl}_{3}$, gave cis-2,6-dihy-

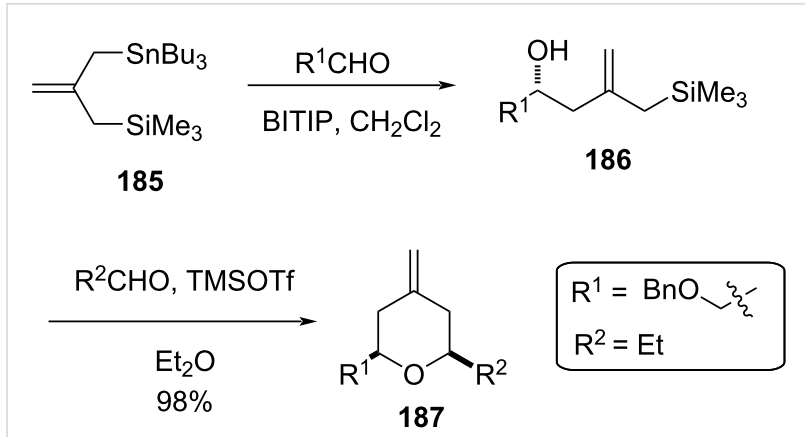

Scheme 45: TMSOTf-promoted annulation reaction.

dropyran 190 via chair-like transition state 191. This strategy was further elaborated for the synthesis of 5,6- and 6,6-ringfused dihydropyrans 193 and $\mathbf{1 9 5}$, respectively, as shown in Scheme 46.

A similar tandem strategy of an addition of vinylsilane 196, followed by silyl-Prins cyclization with an aldehyde 197 in the presence of $5 \mathrm{~mol} \% \mathrm{BiBr}_{3}$, was reported by Hinkle and co-workers to give the corresponding compound 198 (Scheme 47) [18].

The authors further investigated the Mukaiyama aldol reaction between the $\beta, \gamma$-unsaturated aldehyde 199 and acetal 200 in the presence of $10 \mathrm{~mol} \% \mathrm{BiBr}_{3}$ to obtain aldol product 201. However, the addition of 2 equiv of phenylacetaldehyde (189) and $10 \mathrm{~mol} \% \mathrm{BiBr}_{3}$ afforded dihydropyran $\mathbf{2 0 2}$ in $64 \%$ yield as a single isomer, as shown in Scheme 48 [91].

The cis-2,6-disubstituted tetrahydropyran 207 with two adjacent methylene groups at the $\mathrm{C} 3$ and $\mathrm{C} 4$ positions was synthesized via silyl-Prins cyclization of silane $\mathbf{2 0 5}$ with an aldehyde

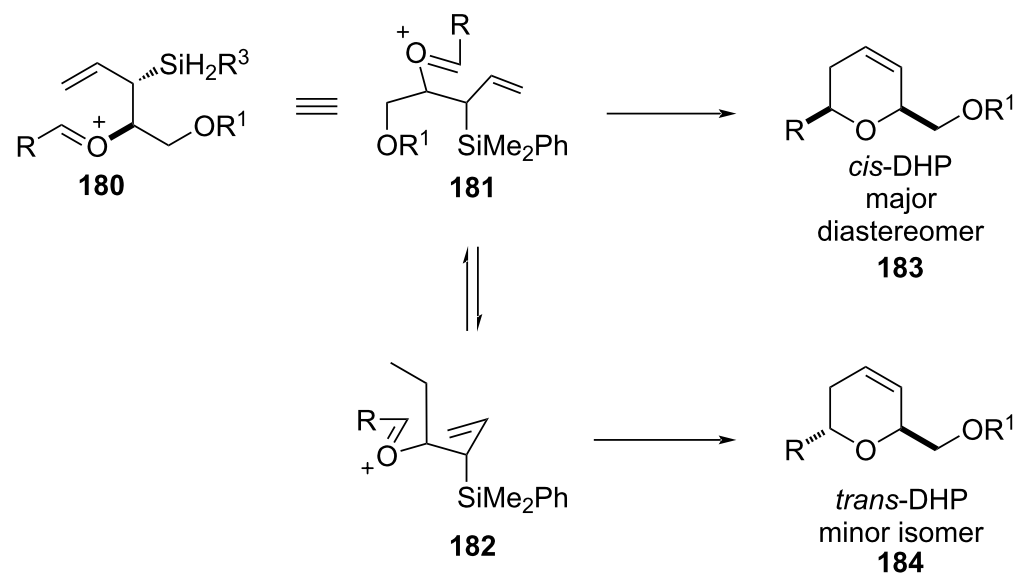




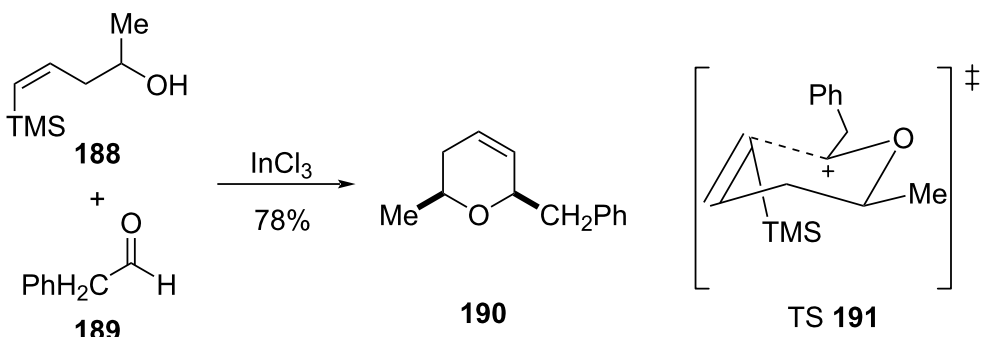

189
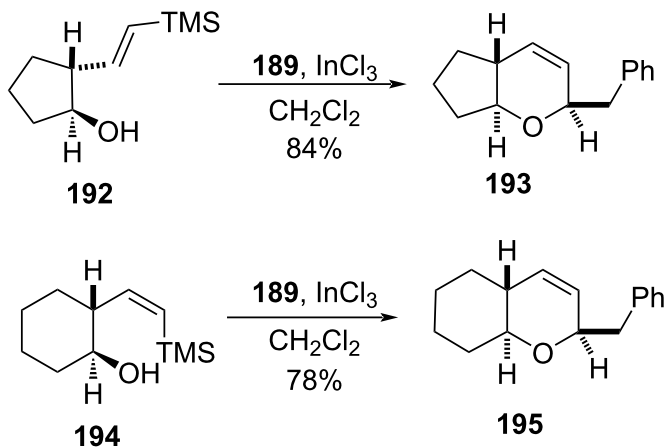

Scheme 46: Dobb and co-workers' synthesis of DHP.

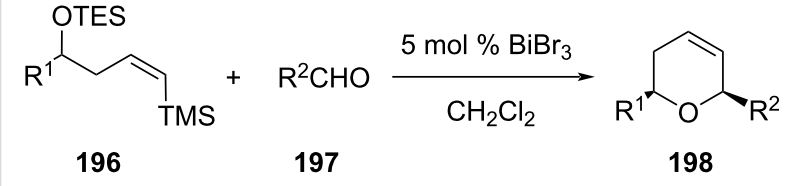

Scheme 47: $\mathrm{BiBr}_{3}$-promoted tandem silyl-Prins reaction by Hinkle et al.

in the presence of Lewis acid TMSOTf [92]. The reaction proceeded through transition state $\mathbf{2 0 8}$ following silyl-Prins cyclization, as shown in Scheme 49.
Unlike allyl- and vinylsilanes, as discussed earlier, Furman and co-workers introduced a new concept of synthesizing 211 utilizing silyl-Prins cyclization of propargylsilane $\mathbf{2 0 9}$ and aldehyde $\mathbf{2 1 0}$ in the presence of TMSOTf [93]. The oxocarbenium ion was intramolecularly trapped by the olefin, followed by removal of trimethylsilane (Scheme 50).

The authors further explored this strategy for the asymmetric synthesis of 3-vinylidene-substituted tetrahydropyran by taking the chiral propargylsilane. A diastereoselective route to cis-2,6disubstituted tetrahydropyran-4-one $\mathbf{2 1 5}$ was explored by introducing a silyl enol ether Prins cyclization concept in which<smiles>C/C=C\CC(OC(C)(C)C(=O)OC)C(C)(C)C(=O)OC</smiles>

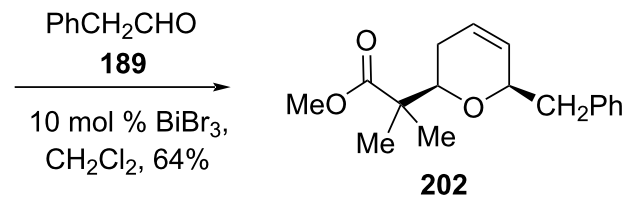




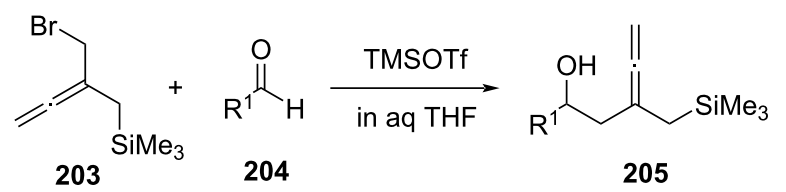<smiles>[R]C1CC(=C)C(=C)OC1[R]</smiles>

$207,61-100 \%$

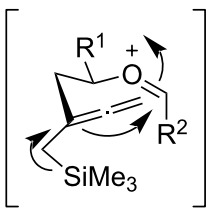

208

Scheme 49: Cho and co-workers' strategy for 2,6 disubstituted 3,4dimethylene-THP.

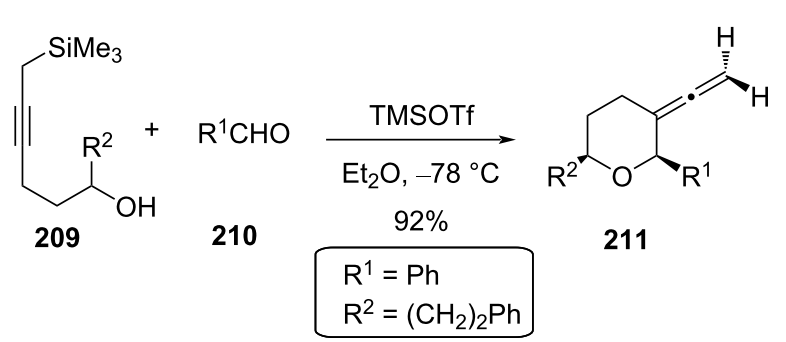

Scheme 50: Furman and co-workers' THP synthesis from propargylsilane.

oxocarbenium ion 214, generated by reacting hydroxy-substituted silyl enol ether $\mathbf{2 1 2}$ with aldehyde $\mathbf{2 1 3}$ (different types of aliphatic and aromatic as well as $\alpha, \beta$-unsaturated aldehydes were used), was trapped by silyl enol ether [94]. A detailed mechanism similar to simple Prins cyclization, except trapping of oxocarbenium ion $\mathbf{2 1 4}$ with silyl enol ether instead of olefin, vinylsilane, or allylsilanes, was proposed as shown in Scheme 51.

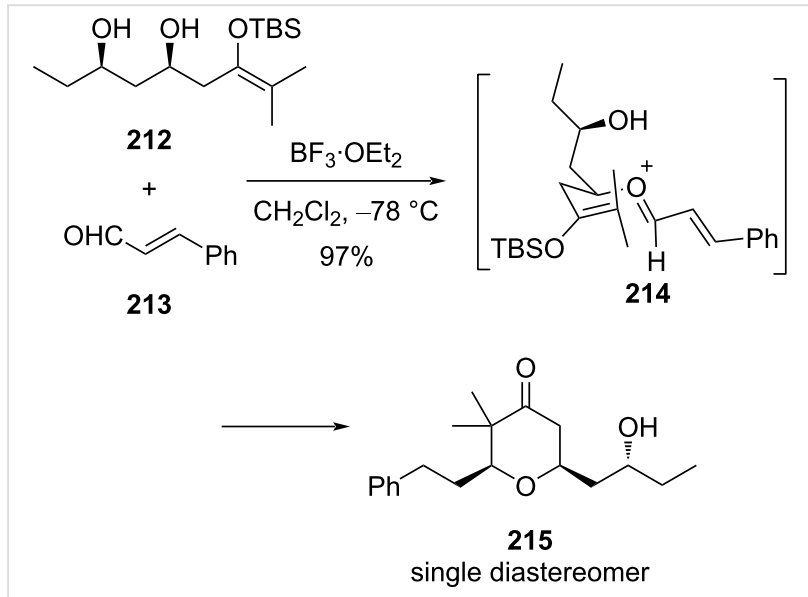

Scheme 51: THP synthesis from silyl enol ethers.

However, the reaction of silyl enol ether such as 216, upon reacting with an unsaturated aldehyde $\mathbf{2 1 7}$, produced a mixture of cis- and trans-220 ( $\mathrm{dr}=4.1: 1.0)$. It was explained that the diastereoselectivity of the product depends on the size of the substituent. For example, when the substituent is sterically small, it occupies the pseudoaxial position in the reactive conformation 218 (Scheme 52).

Li et al. utilized allylic geminal bissilyl alcohol $\mathbf{2 2 1}$ for the construction of THP ring A of (-)-exiguolide via Prins cyclization with an aldehyde in the presence of Lewis acid as a promoter [95]. High yield and excellent diastereoselectivity were obtained under standard silyl-Prins cyclization conditions using TMSOTf as Lewis acid (Scheme 53).

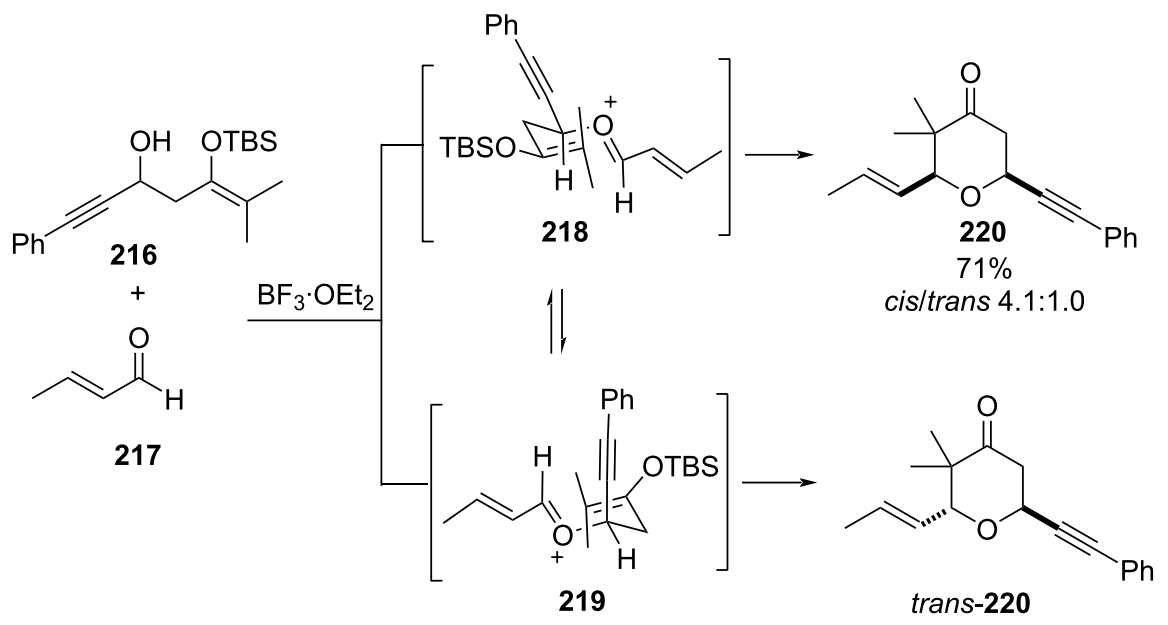

Scheme 52: Rychnovsky and co-workers' strategy for THP synthesis from hydroxy-substituted silyl enol ethers. 


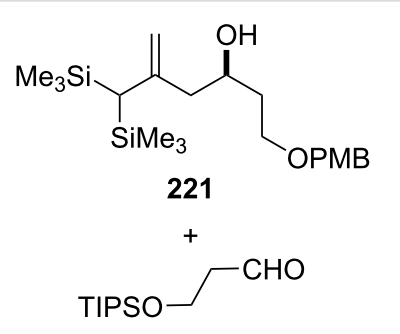

222
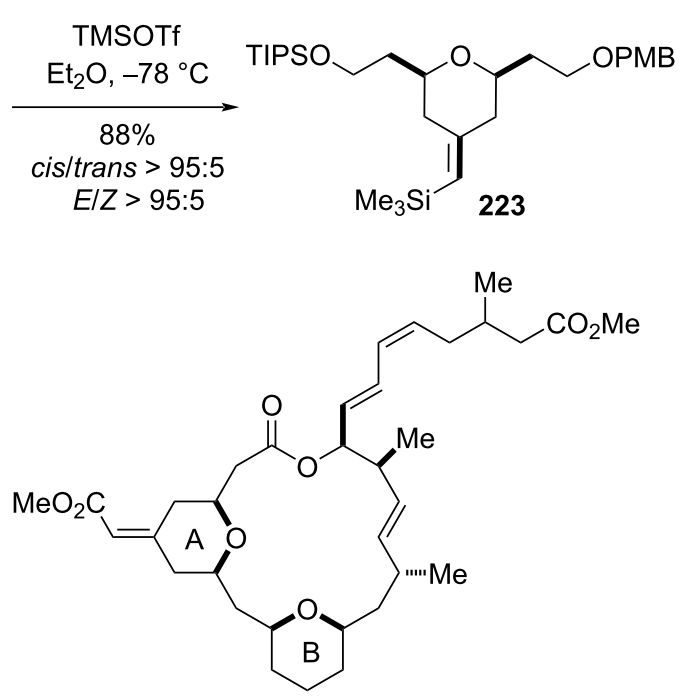

(-)-exiguolide

Scheme 53: Li and co-workers' germinal bissilyl Prins cyclization strategy to (-)-exiguolide.

Recently Xu et al. reported the homoallylic silyl alcohol 224 containing a multisubstituted $(Z)$-alkene reacting with an aldehyde in the presence of TMSI and $\mathrm{InCl}_{3}$ to afford 226 in high diastereoselectivity [96]. The authors assumed that the Prins cyclization proceeded through Alder's chair-like transition state 227 in which the $(Z)$-alkene accounts for the trans-stereocontrol at the $\mathrm{C} 3$ position and equatorial iodide addition accounts for the cis-stereocontrol at the $\mathrm{C} 4$ position, as shown below in Scheme 54.

The one-pot synthesis of tetrahydropyran by utilizing the Babier-Prins cyclization reaction of allyl bromide (228) with a carbonyl compound promoted by $\mathrm{BBIMBr} / \mathrm{SnBr}_{2}$ complex under solvent-free conditions has been explored [97]. The mechanism of the reaction was shown to include a Barbier reaction of allyl bromide with an aldehyde in the presence of $\mathrm{SnBr}_{3}$ and a quaternary ammonium salt to produce allyltin compound 230, which subsequently reacts with an aldehyde to generate intermediate 231. This intermediate could be hydrolyzed by water during workup to afford $\mathbf{2 3 2}$, which does not give the required THP product. Desired product 235 was obtained only in the anhydrous conditions (Scheme 55).

The methodology of alkynylsilane Prins cyclization was explored for the synthesis of 2,6-dihydropyran $\mathbf{2 3 8}$ by reacting secondary homopropargyl alcohol $\mathbf{2 3 6}$, having a trimethylsilyl group at the triple bond, with an aldehyde (Scheme 56) [98101]. The reaction follows alkyne Prins cyclization and minimizes the competitive 2-oxonia-[3,3]-sigmatropic rearrangement pathway. The reaction was highly stereoselective and afforded the cis-2,6-dihydropyran in the presence of Lewis acid $\mathrm{FeCl}_{3}$.

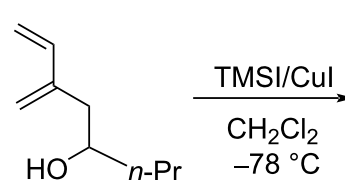

224<smiles>CCCCC(CC(C)=CCI)O[Na]</smiles>

225<smiles>[R]C1C[C@H](P)OC(C)(C)[C@@H]1CI</smiles>

226, 73-85\%

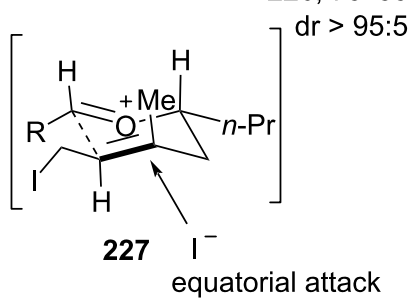

Scheme 54: Xu and co-workers' hydroiodination strategy for THP. 


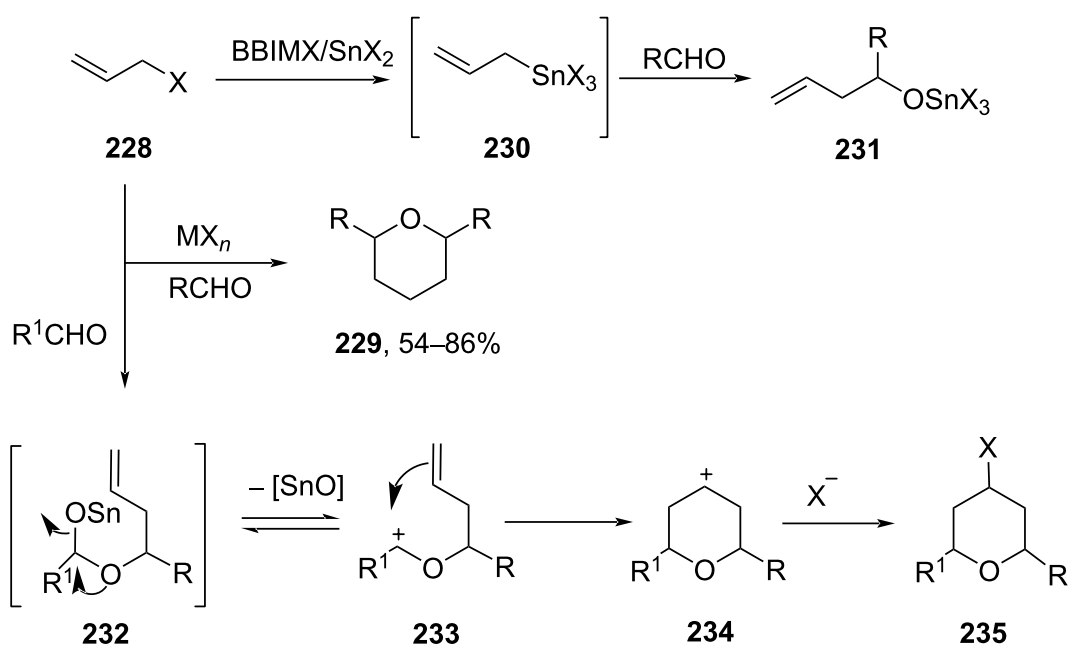

Scheme 55: Wang and co-workers' strategy for tetrahydropyran synthesis.

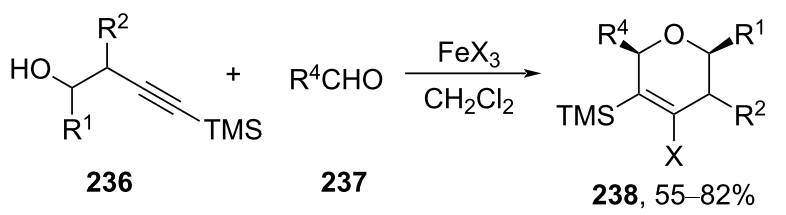

$\mathrm{R}^{1}=\mathrm{R}^{2}=\mathrm{R}^{4}=$ alkyl or aryl $\mathrm{X}=\mathrm{Cl}$ or $\mathrm{Br}$

Scheme 56: $\mathrm{FeCl}_{3}$-catalyzed synthesis of DHP from alkynylsilane alcohol.

From DFT calculations, the authors concluded that the Prins product is formed more rapidly than the $\alpha$-trimethylsilylalkenyl cation $\mathbf{2 4 2}$ formed by the Grob-type fragmentation
(Scheme 57), which was trapped by the subsequent attack of the halide anion, leading to the formation of Prins product 244. On the basis of theoretical calculations, the authors could conclude factors controlling the alkyne Prins cyclization over formal 2-oxonia-[3,3]-sigmatropic rearrangement.

Furthermore, Markó and co-workers successfully synthesized 2,6-anti-configured THP starting from allylsilane $\mathbf{2 4 5}$, following diethylaluminium chloride-promoted ene reaction and condensation with an aldehyde 246 [102]. Expected ene adduct 247 was obtained as a $(Z)$-olefin. The addition of $\mathrm{ZnCl}_{2} \cdot \mathrm{Et}_{2} \mathrm{O}$ and $(\mathrm{MeO})_{3} \mathrm{CH}$ to the resulting homoallylic alcohol 247 leads to the desired pyran derivative $\mathbf{2 4 8}$, having an acetal group at the C2 position (Scheme 58). By treatment of acetal 248 with allyltrimethylsilane gave 2,6-anti-configured THP 249 as a single diastereomer in the presence of TMSOTf.

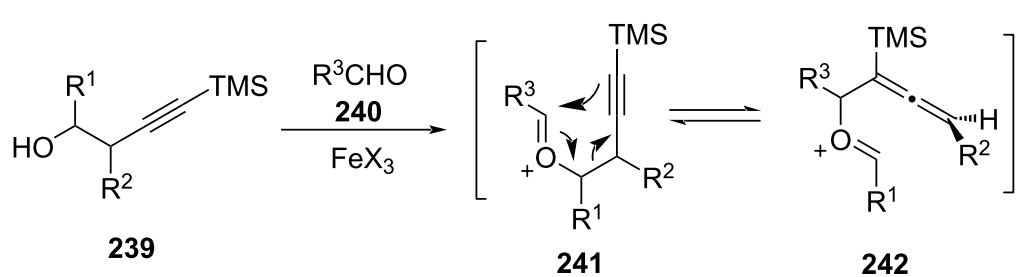

2-oxonia-[3,3]-sigmatropic rearrangement<smiles>[R]C1=[C+]C([Y])C([R])OC1[R14]</smiles> 

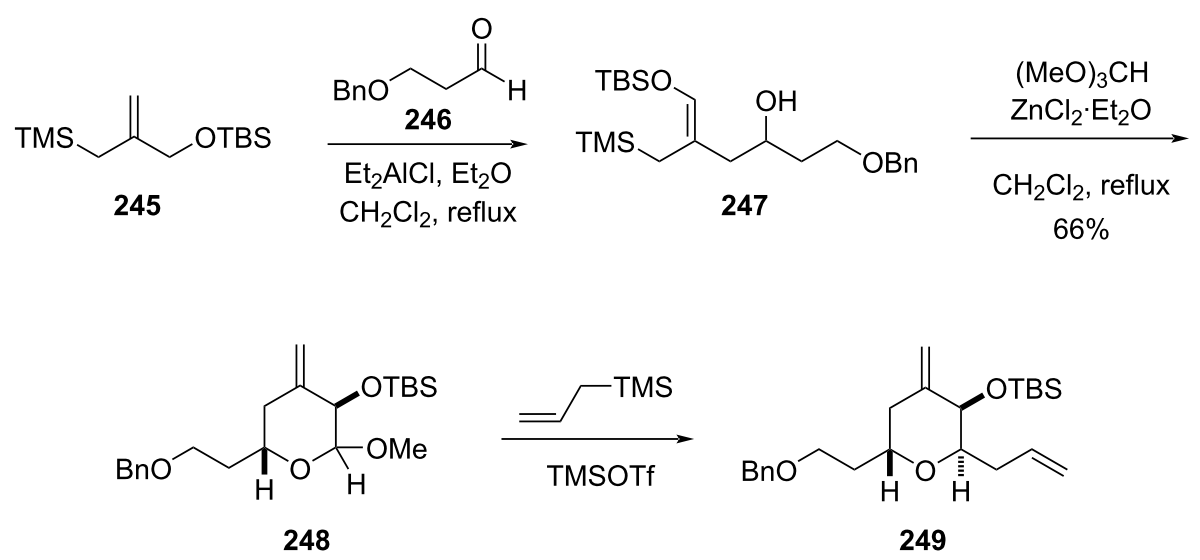

Scheme 58: Marko and co-workers' synthesis of 2,6-anti-configured tetrahydropyran.

A new route to obtain 2,6-anti-configured THP ring 252 was reported using homoallylic $\alpha$-hydroxy ester $\mathbf{2 5 0}$ in an $\operatorname{In}(\mathrm{OTf})_{3^{-}}$ catalyzed Prins cyclization with moderate selectivity. Although selectivity was not observed (almost 1:1), a variety of 2,6-syn and anti-4-chloro-trisubstituted THPs were prepared depending upon nature of $\mathrm{R}^{1}$ in $\mathbf{2 5 0}$. Whereas, particularly with benzoyl ester substituent (250), only syn product $\mathbf{2 5 1}$ was obtained in $69 \%$ yield (Scheme 59) [103].<smiles>[R]C(O)CC=CC(C)(O[Na])c1ccccc1</smiles>

250<smiles>[R]C1CC(Cl)CC([PH2+])O1</smiles>

$251,69 \%$<smiles>[R]C1CC(Cl)CC(Pc2ccccc2)O1</smiles>

252, $0 \%$
Scheme 59: Loh and co-workers' strategy for 2,6-syn-tetrahydropyrans.
The possible mechanism for the formation of a variety of isomers was explained through transition state $\mathbf{2 5 4}$ and $\mathbf{2 5 5}$ (Scheme 60). Competition between electronically favored transition state $\mathbf{2 5 4}$ leads to the formation of anti-isomer $\mathbf{2 5 6}$, whereas the sterically preferred transition state $\mathbf{2 5 5}$ afforded syn-isomer 257.

Unlike the well-explored selective synthesis of major cis-2,6THP, a highly stereoselective route to the thermodynamically disfavored trans-2,6-tetrahydropyran $\mathbf{2 6 0}$ was reported by Cha and co-workers based on the coupling of hydroxyethyl-tethered cyclopropanol 258 and aliphatic aldehyde 259 using $\mathrm{TiCl}_{4}$ as a Lewis acid [104,105]. The reaction proceeded through the Prins cyclization (Scheme 61).

The reaction proceeded via formation of a 7-membered cyclic acetal $\mathbf{2 6 3}$ as a single isomer in nearly quantitative yield, followed by Lewis acid-catalyzed rearrangement leading to the

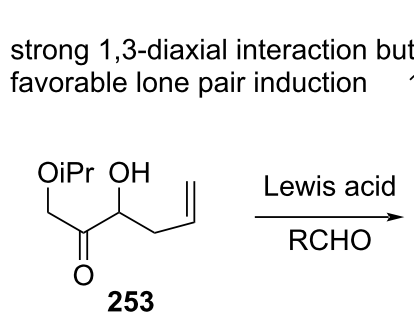

strain-free configuration having remote lone pair induction effect

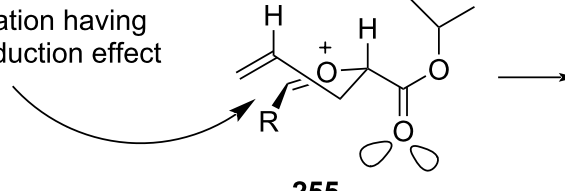

255

$\beta$-oxonium ion<smiles>CC(=O)OC(C)C(=O)OC(C)C</smiles>

254

11 $\alpha$-oxonium ion<smiles>[R]C1C[C@@H](Cl)C[C@@H](C(=O)OC(C)C)O1</smiles>

anti-THP<smiles>[R]C1C[C@@H](Cl)C[C@@H](C(=O)OC(C)C)O1</smiles>

257

syn-THP 


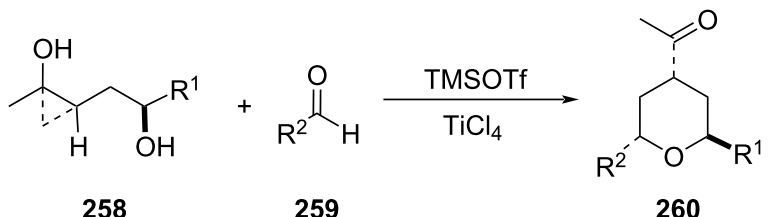

258

259

$90 \%, d r=12: 1$ aforementioned 7-membered cyclic acetal strategy. The treatment of $\alpha$-acetoxy ether $\mathbf{2 6 6}$ with Lewis acid produced the corresponding THP $\mathbf{2 6 7}$ with moderate diastereoselectivity in favor of the trans-2,6-stereoisomer, as shown in Scheme 63.

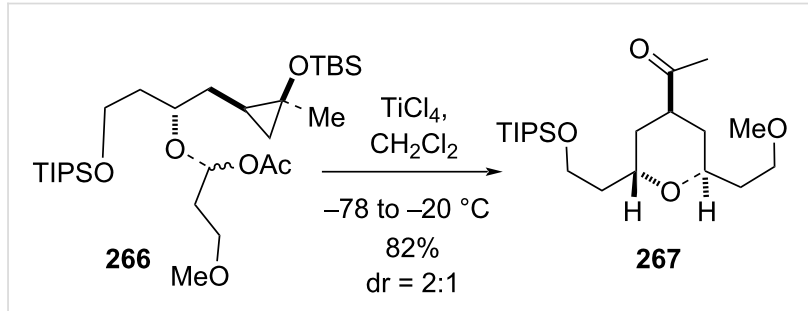

Scheme 63: $\mathrm{TiCl}_{4}$-mediated cyclization to trans-THP.

tions, TMSOTf gave 7-membered cyclic acetal 263, which upon treatment with $\mathrm{TiCl}_{4}$ gave the desired THP as a 14:1 mixture of trans- and cis-265 in 80\% yield. The trans-265 was obtained as a major isomer, where the reaction proceeded through the 6-membered chair-like transition state 264, and the electrophilic ring opening of cyclopropane by the oxocarbenium ion was believed to proceed via "corner attack" at the less substituted $\mathrm{C}-\mathrm{C}$ bond. However, minor cis-265 was formed via the 6-membered boat like transition state 264' (Scheme 62) [104].

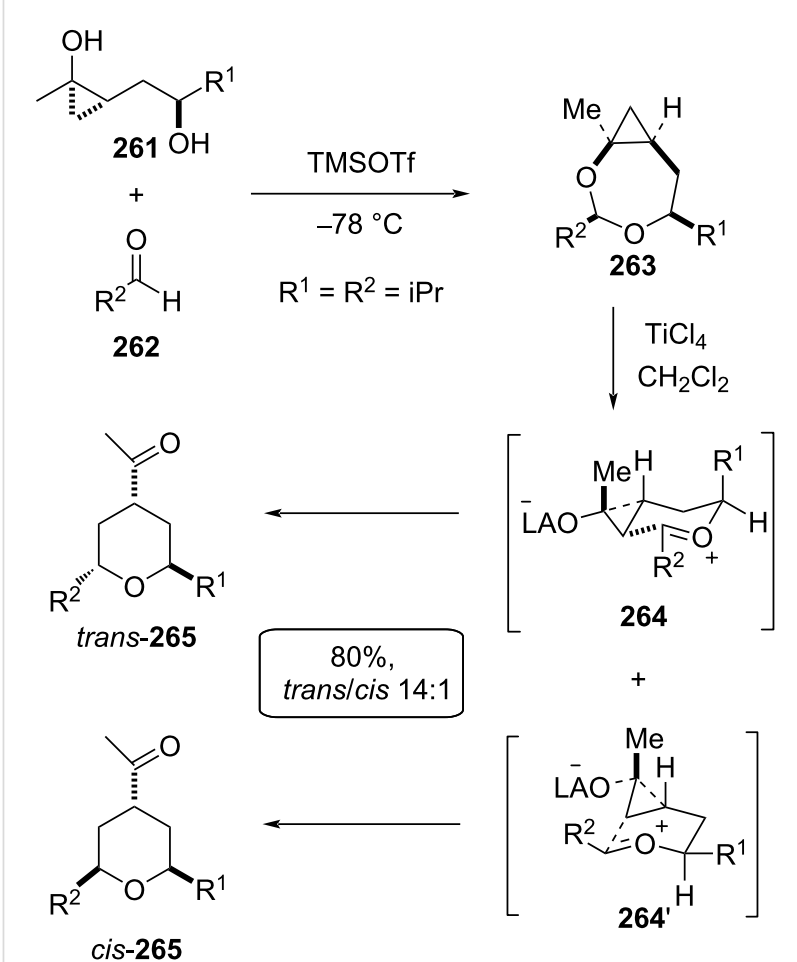

Scheme 62: Mechanism proposed by Cha et al.

Cha's group also utilized the Rechnovsky convergent method where an $\alpha$-acetoxy ether was used as a precursor for the oxocarbenium ion in the THP synthesis to complement the
A variety of 4-hydroxy-substituted THPs was exclusively generated via Prins reaction using $\mathrm{FeCl}_{3}$ as a Lewis acid catalyst. Excellent stereoselectivity was obtained for a remarkably broad range of substrates under mild reaction conditions (Scheme 64) [106].

$$
\text { (268) }
$$

Scheme 64: Feng and co-workers' $\mathrm{FeCl}_{3}$-catalyzed Prins cyclization strategy to 4-hydroxy-substituted THP.

The authors proposed fundamental insights into the mechanism of the reaction based on DFT calculations. A different $[2+2]$-cycloaddition process was suggested to rationalize the observed $\mathrm{OH}$-selectivity.

In 2015, Padrón and co-workers also reported the Prins cyclization catalyzed by a $\mathrm{Fe}(\mathrm{III})$ and trimethylsilyl halide system for the synthesis of all-cis-2,4,6-trisubstituted THP [107]. As reported previously by Feng et al. [106], two mechanistic pathways via the classical oxocarbenium route and [2+2]-cycloaddition were considered for DFT calculations. Experimental and DFT studies suggested the preference of a classical oxocarbenium route over the $[2+2]$-pathway for those alcohols having unactivated and unsubstituted alkenes, whereas the substituent adjacent to the hydroxy group in the homoallylic alcohol 
controls the oxonia-Cope rearrangement (see 273a-c). The alkyl substituent favored the exclusive formation of crossed THP derivatives, whereas 2-oxonia-Cope rearrangement was thermodynamically favored in the presence of a phenyl group (Scheme 65).

Matsumoto and co-workers reported a Lewis acid-mediated Prins cyclization between an alcohol 278 bearing a nonconjugated diene moiety and an aldehyde $\mathbf{2 7 7}$ with alkyl or aryl substituent in presence of $\mathrm{BF}_{3} \cdot \mathrm{Et}_{2} \mathrm{O}$ and $\mathrm{TMSCl}$ at $-40{ }^{\circ} \mathrm{C}$ to afford corresponding fluorinated bicyclic compound 284 [108]. A catalytic amount of TMSCl generates TMS-protected alcohol 279 and $\mathrm{HCl}$. The activated aldehyde $\mathbf{2 8 0}$ reacts with $\mathbf{2 7 9}$ to form the intermediate $\mathbf{2 8 1}$. Then, the TMS group in $\mathbf{2 8 1}$ is attacked by $\mathrm{F}^{-}$in the presence of $\mathrm{HCl}$ to give the alkoxycarbenium ion intermediate $\mathbf{2 8 2}$, which is followed by a sequential cyclization to form secondary carbocation $\mathbf{2 8 3}$, which in the presence of fluoride ions affords $\mathbf{2 8 4}$, as shown in Scheme 66.

Banerjee et al. explored the reactivity of cyclopropane carbaldehydes 285 with 3-butyn-1-ol in the presence of $\mathrm{TiX}_{4}$ for the stereoselective construction of the THF ring (Scheme 67) [109].

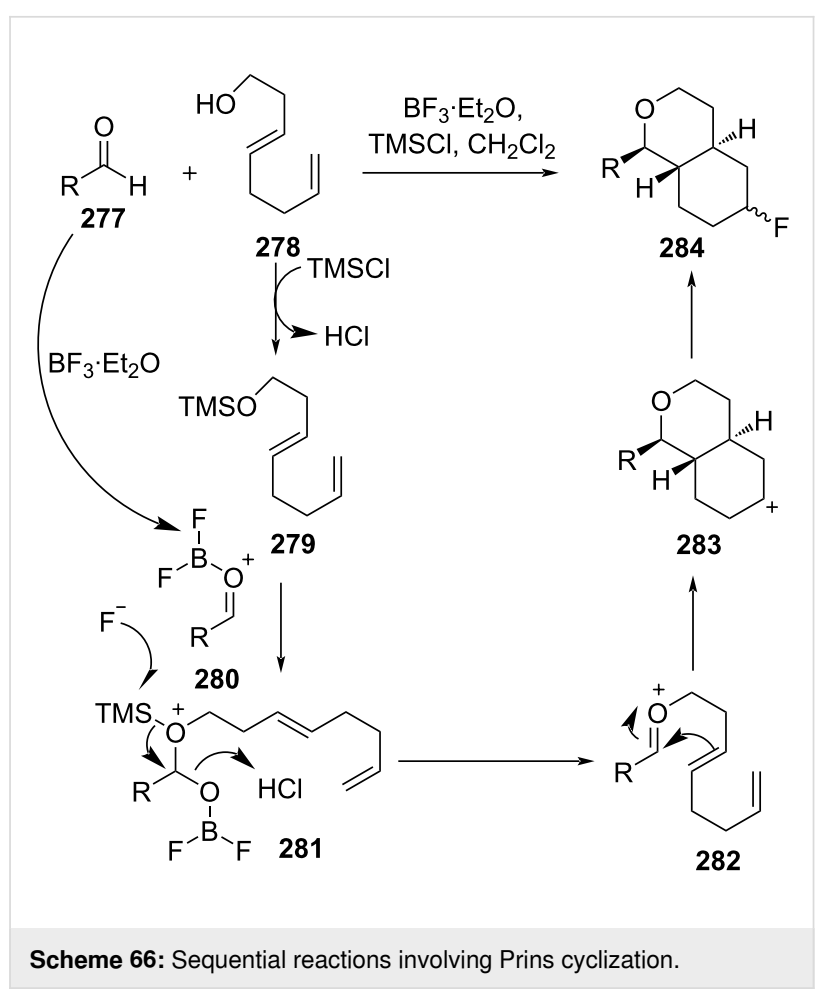

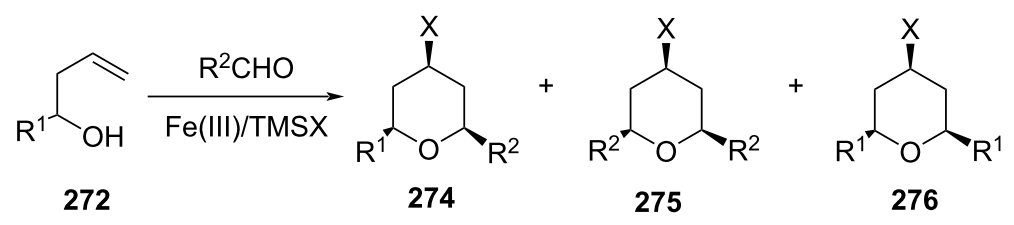

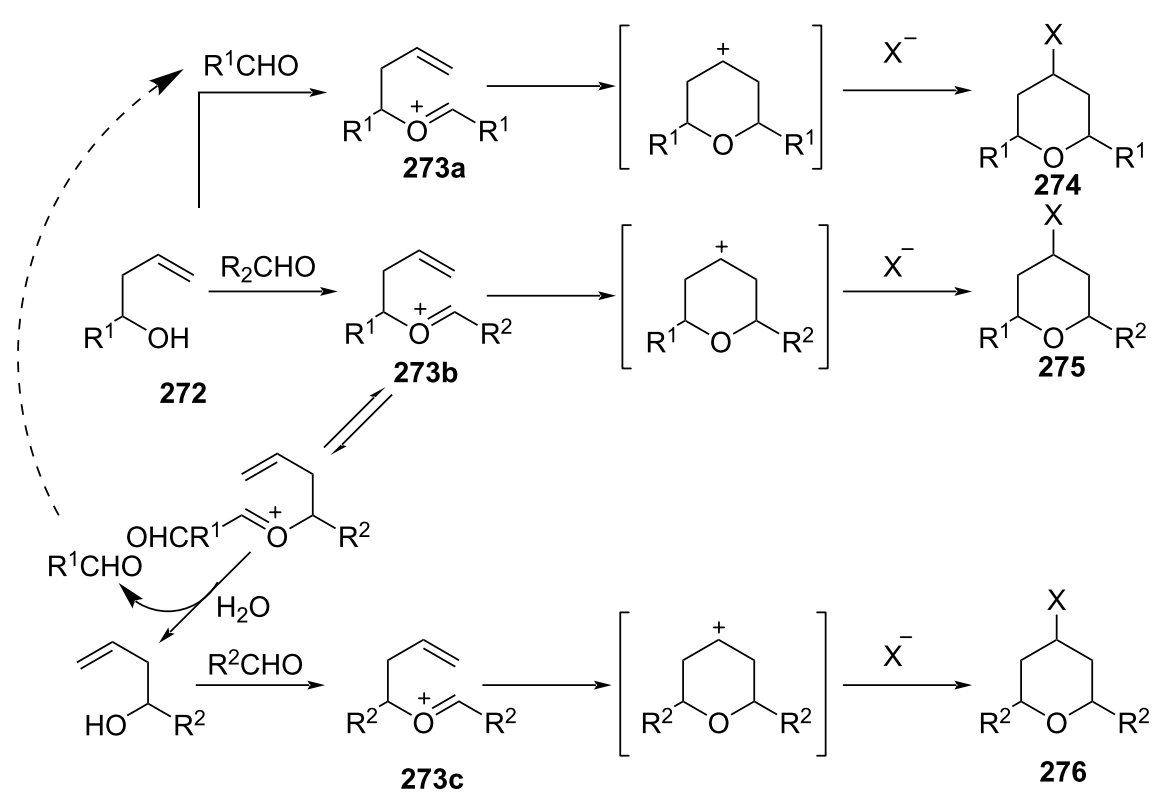


<smiles>O=CC1CC1[18F]</smiles>

285<smiles>C#CCCO</smiles>

286 $\underset{-78^{\circ} \mathrm{C}, 4 \AA \mathrm{MS}}{\stackrel{\mathrm{TiX}_{4}(1.0 \text { equiv) }}{\longrightarrow}}$ $\mathrm{DCM}$ $\mathrm{X}=\mathrm{Cl}, \mathrm{Br}$<smiles>[Y9]C1CCC2OCCC([X])([X])C12</smiles>

287

major<smiles>[X]C1([X])CCOC2CCC([AlH])C21</smiles>

288

minor

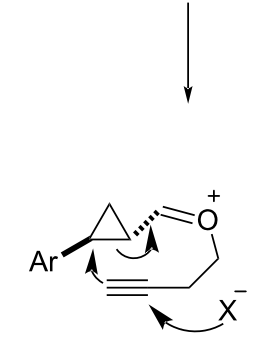

289<smiles>[X]C(=CC(Br)CC)CCCC</smiles>

290<smiles>[X]C([X])=C1CC(CC)OCC1CC</smiles>

291

Scheme 67: Banerjee and co-workers' strategy of Prins cyclization from cyclopropane carbaldehydes and propargyl alcohol.

A series of geminal bishalogen-containing fused THPs was synthesized in high yield (up to $80 \%$ ) and excellent diastereoselectivity. A Prins cyclization mechanism was proposed for the above transformation in the presence of $\mathrm{TiCl}_{4}$. Formation of the oxocarbenium ion $\mathbf{2 8 9}$, followed by an intramolecular nucleophilic attack by the alkynyl bond on the cyclopropane unit gave cyclic oxocarbenium intermediate 290. Further, the attack of a halide anion (from $\mathrm{TiX}_{4}$ ) leads to the Prins cyclization to give bishalogenated bicyclic THP with all-cis-stereochemistry in the major product.

\section{Asymmetric Prins cyclization}

Mullen and Gagné reported a first catalytic asymmetric Prins cyclization reaction between 2-allylphenol 292 and glyoxylate ester 293 using $(R)$-[(tolBINAP)Pt $\left.\left(\mathrm{NC}_{6} \mathrm{~F}_{5}\right)_{2}\right]\left[\mathrm{SbF}_{6}\right]_{2}(\mathbf{2 9 4})$ as chiral catalyst [110]. An optimization study revealed that the enantioselectivity varied with the polarity of the solvent. The optimization study disclosed that the enantioselectivity increases with the decrease of the polarity of the solvent (Scheme 68).

$\mathrm{Yu}$ and co-workers reported a novel segment-coupling Prins cyclization involving sequential benzylic/allylic $\mathrm{C}-\mathrm{H}$ bond activation via DDQ oxidation, followed by nucleophilic attack of an unactivated olefin to obtain all-cis-trisubstituted Prins products with high stereochemical precision [111]. A single-electron transfer (SET) mechanism was proposed for the above transformation (Scheme 69). A SET from an arene or alkene to DDQ and the subsequent abstraction of hydride from the benzylic or allylic position generated a charge-transfer complex<smiles>[CH2+]C(C)=CCc1ccccc1O</smiles>

292<smiles>CCCCOC(=O)C=O</smiles>

293

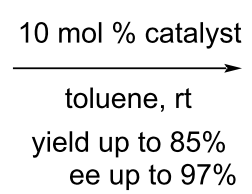<smiles>CC(C)(C)OC(=O)C(O)C1Cc2ccccc2OC1(C)C</smiles>

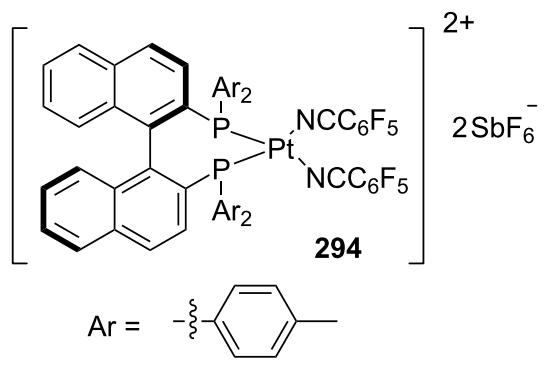



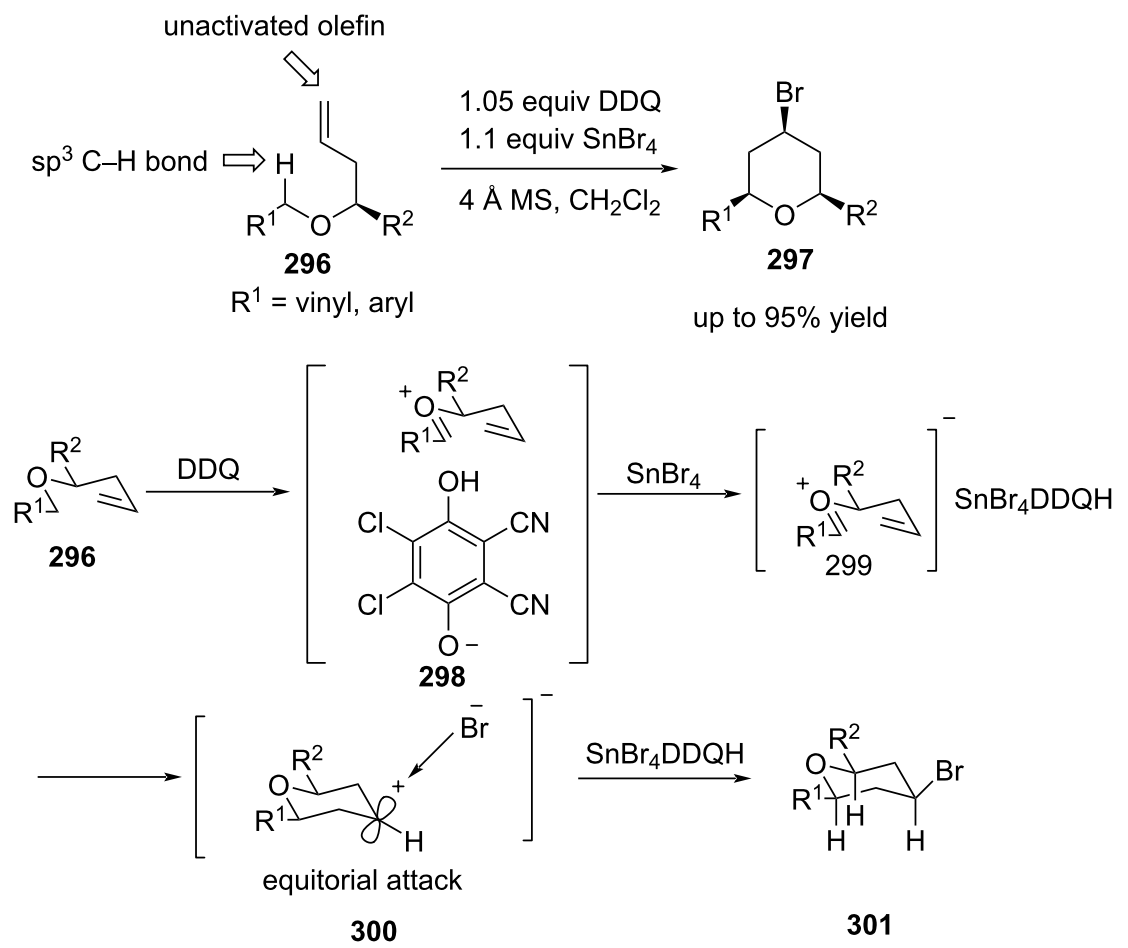

Scheme 69: Yu and co-workers' DDQ-catalyzed asymmetric Prins cyclization strategy to trisubstituted THPs.

298. The complex 298 formed a tin-containing ate oxocarbenium ion complex 299 with $\mathrm{SnBr}_{4}$, and then rapid $\mathrm{C}-\mathrm{C}$ bond formation took place to generate the cyclic intermediate $\mathbf{3 0 0}$ The subsequent trapping of the carbocation with the bromide ion led to all-cis-2,4,6-trisubstituted tetrahydropyran $\mathbf{2 9 7}$ (Scheme 69).

Lalli and van de Weghe reported a chiral BINOL-derived bisphosphoric acid- and $\mathrm{CuCl}$-catalyzed enantioselective tandem Prins-Friedel-Crafts cyclization between homoallylic alcohol $\mathbf{3 0 2}$ and substituted aromatic aldehydes $\mathbf{3 0 3}$ to form hexahydro$1 H$-benzo[f]isochromenes $\mathbf{3 0 5}$ with three new contiguous stereocenters in high enantio- and diastereoselectivity [112] The three new contiguous stereogenic centers formed resulted from an attack of the alkene to the $\mathrm{Si}$-face of the oxocarbenium ion, which was followed by a completely diastereoselective Friedel-Crafts reaction (Scheme 70).

List and co-workers devised a strategy employing highly acidic confined iminoimidodiphosphate (iIDP) Brønsted acids $\mathbf{3 0 8}$ that catalyzed asymmetric Prins cyclizations of both aliphatic and aromatic aldehydes with alcohol 307 to obtain 309 (Scheme 71) [113]. The introduction of electron-withdrawing nitro groups on the BINOL backbone in the catalysts significantly enhanced the reactivity and enantioselectivity.

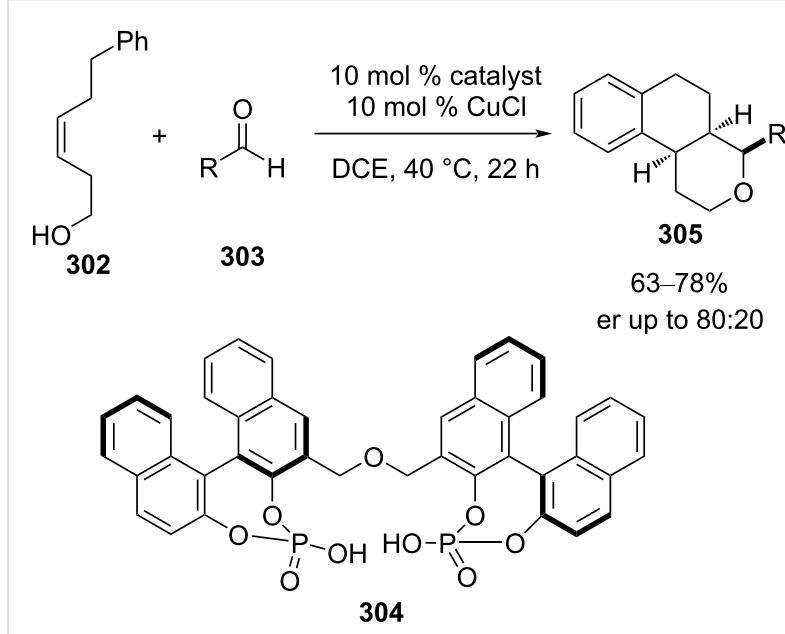

Scheme 70: Lalli and Weghe's chiral-Brønsted-acid- and achiralLewis-acid-promoted asymmetric Prins cyclization strategy.

Zhou et al. reported an asymmetric Prins cyclization of in situgenerated quinone methides from phenol-tethered alkenyl alcohol 310 and $o$-aminobenzaldehyde 311 using chiral phosphoric acids (Scheme 72) [114]. Diverse functionalized transfused pyranotetrahydroquinoline derivatives $\mathbf{3 1 2}$ were synthesized in excellent yield and selectivity (up to $99 \%$ yield and $99 \%$ ee) 

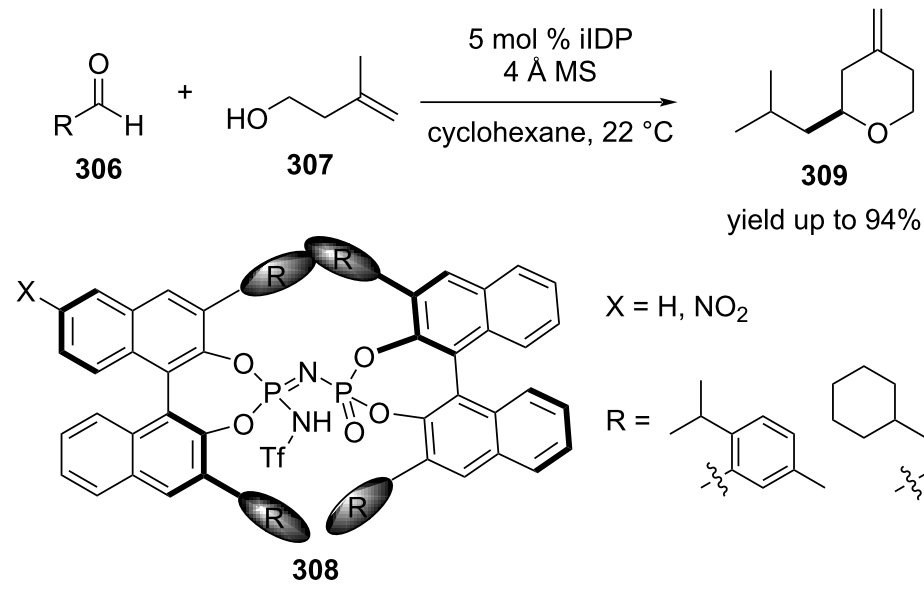

yield up to $94 \%$

$\mathrm{X}=\mathrm{H}, \mathrm{NO}_{2}$<smiles>[R]=C(C)c1ccc(C)cc1C</smiles>

Scheme 71: List and co-workers' ilDP Brønsted acid-promoted asymmetric Prins cyclization strategy.

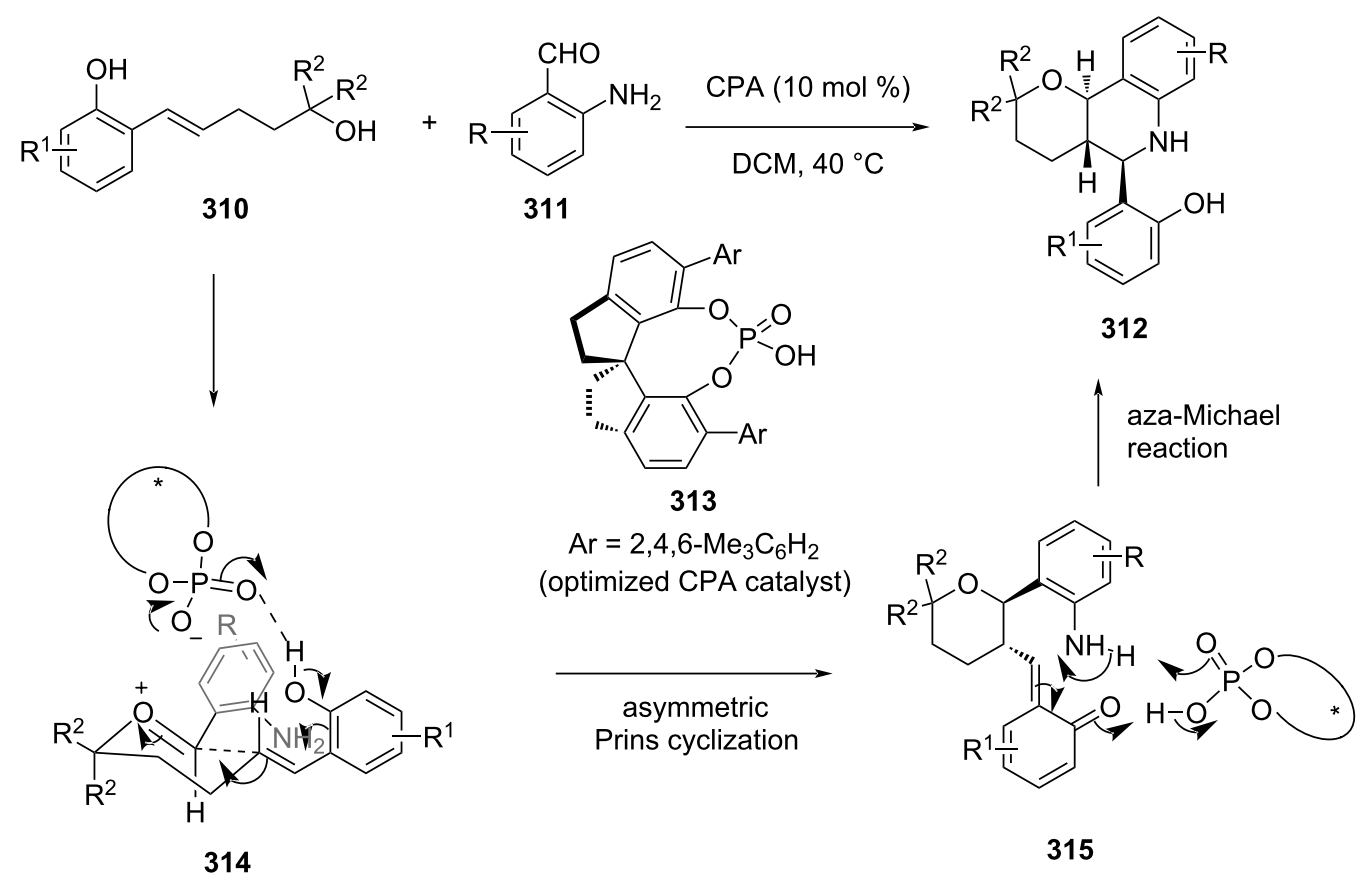

Scheme 72: Zhou and co-workers' strategy for chiral phosphoric acid (CPA)-catalyzed cascade Prins cyclization.

List et al. reported a chiral imidodiphosphoric acid-catalyzed asymmetric Prins cyclization with salicylaldehyde 316 and 3-methylbut-3-en-1-ol (317) to afford 4-methylenetetrahydropyrans 318 with high enantioselectivity (Scheme 73) [115]. A chiral bis-BINOL-based imidophosphoric acid 319 was efficient in this reaction, and the extreme bulkiness of this catalyst was the key to a successful transformation. This reaction proceeded via a Prins cyclization mechanism, activated by chiral acid 319.

\section{Conclusion}

Prins cyclization strategies have been proven as a reliable and robust method for the stereoselective construction of THP rings. Many of these strategies have been utilized for the elegant synthesis of natural products. In this review, we portrayed an inspection of twenty years in the arena of the development of Prins cyclizations and the further exploration of these strategies in the total synthesis of natural products. This up-to-date information showcases the knowledge gained in this area. In either 
<smiles>[R]c1ccc(O)c(C(=O)[CH+][CH2+])c1</smiles>
$\underset{\text { cyclohexane }}{\stackrel{\text { cat. }(5 \mathrm{~mol} \%)}{\longrightarrow}}$
$5 \AA \mathrm{MS}, \mathrm{rt}, 5 \mathrm{~d}$ 317 316<smiles>[X]Oc1ccccc1C1=[O+]CCC(C)=C1</smiles>
320<smiles>[R]c1ccc(O)c(C2CC(=C)CCO2)c1</smiles>

318<smiles>[R]c1cc2ccccc2c(-c2c([R])cc3ccccc3c2OP(=O)(O)N=[PH](=O)(Oc2c([R])cc3ccccc3c2[R])Oc2c([R])cc3ccccc3c2[R])c1[R]</smiles><smiles>[R]</smiles><smiles>Cc1ccc(C2CCCCC2)c([Te])c1</smiles>

Scheme 73: List and co-workers' approach for asymmetric Prins cyclization using chiral imidodiphosphoric acid 319.

case, it is hoped that the challenge of stereoselective construction of THP rings in the context of natural product synthesis will continue to inspire synthetic chemists to develop new methods in the coming years.

\section{Acknowledgements}

We sincerely acknowledge Dr. (Prof.) Ganesh Pandey for his critical suggestions in the compiling of this review.

\section{Funding}

A. B. thanks SERB-DST (YSS/2015/001085), India for financial assistance.

\section{ORCID ${ }^{\circledR}$ iDs}

Asha Budakoti - https://orcid.org/0000-0003-3013-1610 Jagadish Khamrai - https://orcid.org/0000-0002-2883-0087

\section{References}

1. Olier, C.; Kaafarani, M.; Gastaldi, S.; Bertrand, M. P. Tetrahedron 2010, 66, 413-445. doi:10.1016/j.tet.2009.10.069

2. Overman, L. E.; Pennington, L. D. J. Org. Chem. 2003, 68, 7143-7157. doi:10.1021/jo034982c

3. Boger, D. L.; Weinreb, S. M. Hetero Diels-Alder Methodology in Organic Synthesis; Academic Press: San Diego, CA, USA, 1987.

4. Nicolaou, K. C.; Prasad, C. V. C.; Somers, P. K.; Hwang, C. K. J. Am. Chem. Soc. 1989, 111, 5330-5334. doi:10.1021/ja00196a043

5. Kas'yan, L. I.; Pal'chikov, V. A.; Bondarenko, Ya. S. Russ. J. Org. Chem. 2011, 47, 1609-1652. doi:10.1134/s1070428011110017

6. Smith, A. B.; Fox, R. J.; Razler, T. M. Acc. Chem. Res. 2008, 41, 675-687. doi:10.1021/ar700234r

7. Padmaja, P.; Reddy, P. N.; Subba Reddy, B. V. Org. Biomol. Chem. 2020, 18, 7514-7532. doi:10.1039/d0ob00960a

8. Rapelli, C.; Sridhar, B.; Subba Reddy, B. V. Org. Biomol. Chem. 2020, 18, 7224. doi:10.1039/d0ob90122a
9. Pastor, I. M.; Yus, M. Curr. Org. Chem. 2007, 11, 925-957. doi:10.2174/138527207781024067

10. Pastor, I. M.; Yus, M. Curr. Org. Chem. 2012, 16, 1277-1312. doi:10.2174/138527212800564196

11. Heravi, M. M.; Ahmadi, T.; Ghavidel, M.; Heidari, B.; Hamidi, H. RSC Adv. 2015, 5, 101999-102075. doi:10.1039/c5ra17488k

12. Vilotijevic, I.; Jamison, T. F. Angew. Chem., Int. Ed. 2009, 48, 5250-5281. doi:10.1002/anie.200900600

13. Minbiole, E. C.; Minbiole, K. P. C. J. Antibiot. 2016, 69, 213-219. doi:10.1038/ja.2015.136

14. Nising, C. F.; Bräse, S. Chem. Soc. Rev. 2008, 37, 1218-1228. doi:10.1039/b718357g

15. Abrams, D. J.; Provencher, P. A.; Sorensen, E. J. Chem. Soc. Rev. 2018, 47, 8925-8967. doi:10.1039/c8cs00716k

16. Gradillas, A.; Pérez-Castells, J. Angew. Chem., Int. Ed. 2006, 45, 6086-6101. doi:10.1002/anie.200600641

17. Ko, C.; Hsung, R. P.; Al-Rashid, Z. F.; Feltenberger, J. B.; Lu, T.; Yang, J.-H.; Wei, Y.; Zificsak, C. A. Org. Lett. 2007, 9, 4459-4462. doi:10.1021/ol701768n

18. Evans, P. A.; Cui, J.; Gharpure, S. J.; Hinkle, R. J. J. Am. Chem. Soc. 2003, 125, 11456-11457. doi:10.1021/ja036439j

19. Evans, P. A.; Cui, J.; Gharpure, S. J. Org. Lett. 2003, 5, 3883-3885. doi:10.1021/ol035438t

20. Miranda, P. O.; Díaz, D. D.; Padrón, J. I.; Bermejo, J.; Martín, V. S. Org. Lett. 2003, 5, 1979-1982. doi:10.1021/01034568z

21. Marcos, R.; Rodríguez-Escrich, C.; Herrerías, C. I.; Pericàs, M. A. J. Am. Chem. Soc. 2008, 130, 16838-16839. doi:10.1021/ja8062887

22. Kriewitz, O. Ber. Dtsch. Chem. Ges. 1899, 32, 57-60. doi:10.1002/cber.18990320111

23. Bloys Van Treslong Prins, P. C. Chem. Weekbl. 1919, 1510.

24. Bloys Van Treslong Prins, P. C. Chem. Weekbl. 1919, 1072.

25. Hanschke, E. Chem. Ber. 1955, 88, 1053-1061. doi:10.1002/cber.19550880718

26. Perry, M. A.; Rychnovsky, S. D.; Sizemore, N. Synthesis of Saturated Tetrahydropyrans. In Synthesis of Saturated Oxygenated Heterocycles I; Cossy, J., Ed.; Topics in Heterocyclic Chemistry, Vol. 35; Springer: Berlin, Heidelberg, Germany, 2014; pp $978 \mathrm{ff}$. doi:10.1007/978-3-642-41473-2_2

27. Nasir, N. M.; Ermanis, K.; Clarke, P. A. Org. Biomol. Chem. 2014, 12, 3323-3335. doi:10.1039/c4ob00423j 
28. Alder, R. W.; Harvey, J. N.; Oakley, M. T. J. Am. Chem. Soc. 2002, 124, 4960-4961. doi:10.1021/ja025902+

29. Crosby, S. R.; Harding, J. R.; King, C. D.; Parker, G. D.; Willis, C. L. Org. Lett. 2002, 4, 577-580. doi:10.1021/ol0102850

30. Barry, C. S. J.; Crosby, S. R.; Harding, J. R.; Hughes, R. A.; King, C. D.; Parker, G. D.; Willis, C. L. Org. Lett. 2003, 5, 2429-2432. doi:10.1021/ol0346180

31. Al-Mutairi, E. H.; Crosby, S. R.; Darzi, J.; Hughes, R. A.; Simpson, T. J.; Smith, R. W.; Willis, C. L.; Harding, J. R.; King, C. D. Chem. Commun. 2001, 835-836. doi:10.1039/b101414p

32. Rychnovsky, S. D.; Marumoto, S.; Jaber, J. J. Org. Lett. 2001, 3, 3815-3818. doi:10.1021/ol0168465

33. Marumoto, S.; Jaber, J. J.; Vitale, J. P.; Rychnovsky, S. D. Org. Lett. 2002, 4, 3919-3922. doi:10.1021/ol026751i

34. Jaber, J. J.; Mitsui, K.; Rychnovsky, S. D. J. Org. Chem. 2001, 66, 4679-4686. doi:10.1021/jo010232w

35. Jasti, R.; Anderson, C. D.; Rychnovsky, S. D. J. Am. Chem. Soc. 2005, 127, 9939-9945. doi:10.1021/ja0518326

36. Rychnovsky, S. D.; Thomas, C. R. Org. Lett. 2000, 2, 1217-1219. doi:10.1021/ol005646a

37. Jasti, R.; Vitale, J.; Rychnovsky, S. D. J. Am. Chem. Soc. 2004, 126, 9904-9905. doi:10.1021/ja046972e

38. Jasti, R.; Rychnovsky, S. D. Org. Lett. 2006, 8, 2175-2178. doi:10.1021/ol0606738

39. Gesinski, M. R.; Van Orden, L. J.; Rychnovsky, S. D. Synlett 2008, 363-366. doi:10.1055/s-2008-1032053

40. Kopecky, D. J.; Rychnovsky, S. D. J. Am. Chem. Soc. 2001, 123, 8420-8421. doi:10.1021/ja011377n

41. Van Orden, L. J.; Patterson, B. D.; Rychnovsky, S. D. J. Org. Chem. 2007, 72, 5784-5793. doi:10.1021/jo070901r

42. Patterson, B.; Marumoto, S.; Rychnovsky, S. D. Org. Lett. 2003, 5, 3163-3166. doi:10.1021/ol035303n

43. Cheung, L. L.; Marumoto, S.; Anderson, C. D.; Rychnovsky, S. D. Org. Lett. 2008, 10, 3101-3104. doi:10.1021/ol8011474

44. Hart, D. J.; Bennett, C. E. Org. Lett. 2003, 5, 1499-1502. doi:10.1021/ol0342756

45. Ko, H. M.; Lee, D. G.; Kim, M. A.; Kim, H. J.; Park, J.; Lah, M. S.; Lee, E. Org. Lett. 2007, 9, 141-144. doi:10.1021/ol0627956

46. Barry, C. S.; Bushby, N.; Harding, J. R.; Willis, C. L. Org. Lett. 2005, 7, 2683-2686. doi:10.1021/ol050840o

47. Barry, C. S.; Elsworth, J. D.; Seden, P. T.; Bushby, N.; Harding, J. R.; Alder, R. W.; Willis, C. L. Org. Lett. 2006, 8, 3319-3322. doi:10.1021/ol0611705

48. Seden, P. T.; Charmant, J. P. H.; Willis, C. L. Org. Lett. 2008, 10, 1637-1640. doi:10.1021/ol800386d

49. Cons, B. D.; Bunt, A. J.; Bailey, C. D.; Willis, C. L. Org. Lett. 2013, 15, 2046-2049. doi:10.1021/ol400736w

50. Yadav, J. S.; Rahman, M. A.; Reddy, N. M.; Prasad, A. R.; Al Khazim Al Ghamdi, A. Synlett 2014, 25, 661-664. doi:10.1055/s-0033-1340181

51. Janardhan Reddy, P.; Srinivas Reddy, A.; Yadav, J. S.; Subba Reddy, B. V. Tetrahedron Lett. 2012, 53, 4051-4053. doi:10.1016/j.tetlet.2012.05.059

52. Morris, W. J.; Custar, D. W.; Scheidt, K. A. Org. Lett. 2005, 7, 1113-1116. doi:10.1021/ol050093v

53. Puglisi, A.; Lee, A.-L.; Schrock, R. R.; Hoveyda, A. H. Org. Lett. 2006, 8, 1871-1874. doi:10.1021/ol060430f

54. Cossey, K. N.; Funk, R. L. J. Am. Chem. Soc. 2004, 126 12216-12217. doi:10.1021/ja046940r
55. Yadav, V. K.; Vijaya Kumar, N. J. Am. Chem. Soc. 2004, 126, 8652-8653. doi:10.1021/ja048000c

56. Yadav, V. K.; Verma, A. K.; Kumar, P.; Hulikal, V. Chem. Commun. 2014, 50, 15457-15460. doi:10.1039/c4cc07796b

57. Yadav, J. S.; Reddy, B. V. S.; Venugopal, C.; Srinivas, R.; Ramalingam, T. Synth. Commun. 2002, 32, 1803-1808. doi:10.1081/scc-120004059

58. Yadav, J. S.; Reddy, B. V. S.; Kumar, G. G. K. S. N.; Reddy, G. M. Tetrahedron Lett. 2007, 48, 4903-4906. doi:10.1016/j.tetlet.2007.05.056

59. Yadav, J. S.; Reddy, M. S.; Prasad, A. R. Tetrahedron Lett. 2005, 46, 2133-2136. doi:10.1016/j.tetlet.2005.01.121

60. Sabitha, G.; Reddy, K. B.; Reddy, G. S. K. K.; Fatima, N.; Yadav, J. S. Synlett 2005, 2347-2351. doi:10.1055/s-2005-872668

61. Loh, T.-P.; Hu, Q.-Y.; Tan, K.-T.; Cheng, H.-S. Org. Lett. 2001, 3, 2669-2672. doi:10.1021/ol0162280

62. Loh, T.-P.; Yang, J.-Y.; Feng, L.-C.; Zhou, Y. Tetrahedron Lett. 2002, 43, 7193-7196. doi:10.1016/s0040-4039(02)01666-0

63. Chan, K.-P.; Loh, T.-P. Tetrahedron Lett. 2004, 45, 8387-8390. doi:10.1016/j.tetlet.2004.09.049

64. Chan, K.-P.; Loh, T.-P. Org. Lett. 2005, 7, 4491-4494. doi:10.1021/ol051951q

65. Liu, F.; Loh, T.-P. Org. Lett. 2007, 9, 2063-2066. doi:10.1021/ol070506n

66. Biermann, U.; Lützen, A.; Metzger, J. O. Eur. J. Org. Chem. 2006 , 2631-2637. doi:10.1002/ejoc.200500701

67. Álvarez-Méndez, S. J.; Fariña-Ramos, M.; Villalba, M. L.; Perretti, M. D.; García, C.; Moujir, L. M.; Ramírez, M. A.; Martín, V. S. J. Org. Chem. 2018, 83, 9039-9066. doi:10.1021/acs.joc.8b01182

68. Leroy, B.; Markó, I. E. J. Org. Chem. 2002, 67, 8744-8752. doi:10.1021/jo025899c

69. Markó, I. E.; Leroy, B. Tetrahedron Lett. 2000, 41, 7225-7230. doi:10.1016/s0040-4039(00)01179-5

70. Gesinski, M. R.; Rychnovsky, S. D. J. Am. Chem. Soc. 2011, 133, 9727-9729. doi:10.1021/ja204228q

71. Hoye, T. R.; Hu, M. J. Am. Chem. Soc. 2003, 125, 9576-9577. doi:10.1021/ja035579q

72. Pham, M.; Allatabakhsh, A.; Minehan, T. G. J. Org. Chem. 2008, 73, 741-744. doi:10.1021/jo7016857

73. Yu, C.-M.; Lee, J.-Y.; So, B.; Hong, J. Angew. Chem., Int. Ed. 2002, 41, 161-163. doi:10.1002/1521-3773(20020104)41:1<161::aid-anie161>3.0.co;2-n

74. Aubele, D. L.; Lee, C. A.; Floreancig, P. E. Org. Lett. 2003, 5, 4521-4523. doi:10.1021/ol0359259

75. Aubele, D. L.; Wan, S.; Floreancig, P. E. Angew. Chem., Int. Ed. 2005, 44, 3485-3488. doi:10.1002/anie.200500564

76. Huang, H.; Panek, J. S. J. Am. Chem. Soc. 2000, 122, 9836-9837. doi:10.1021/ja002087u

77. Su, Q.; Panek, J. S. J. Am. Chem. Soc. 2004, 126, 2425-2430. doi:10.1021/ja037957x

78. Lowe, J. T.; Panek, J. S. Org. Lett. 2005, 7, 3231-3234. doi:10.1021/ol050982i

79. Zhang, Y.; Panek, J. S. Org. Lett. 2007, 9, 3141-3143. doi:10.1021/ol701427k

80. Lowe, J. T.; Panek, J. S. Org. Lett. 2008, 10, 3813-3816. doi:10.1021/ol801499s

81. Zhu, K.; Panek, J. S. Org. Lett. 2011, 13, 4652-4655 doi:10.1021/ol201863b

82. Roush, W. R.; Dilley, G. J. Synlett 2001, 955-959. doi:10.1055/s-2001-14632 
83. Micalizio, G. C.; Pinchuk, A. N.; Roush, W. R. J. Org. Chem. 2000, 65, 8730-8736. doi:10.1021/jo001236o

84. Sanchez, C. C.; Keck, G. E. Org. Lett. 2005, 7, 3053-3056. doi:10.1021/ol051040g

85. Keck, G. E.; Welch, D. S.; Vivian, P. K. Org. Lett. 2006, 8, 3667-3670. doi:10.1021/ol061173h

86. Keck, G. E.; Kraft, M. B.; Truong, A. P.; Li, W.; Sanchez, C. C.; Kedei, N.; Lewin, N. E.; Blumberg, P. M. J. Am. Chem. Soc. 2008, 130, 6660-6661. doi:10.1021/ja8022169

87. Keck, G. E.; Covel, J. A.; Schiff, T.; Yu, T. Org. Lett. 2002, 4, 1189-1192. doi:10.1021/ol025645d

88. Keck, G. E.; Welch, D. S.; Poudel, Y. B. Tetrahedron Lett. 2006, 47, 8267-8270. doi:10.1016/j.tetlet.2006.09.094

89. Dobbs, A. P.; Guesné, S. J. J.; Martinović, S.; Coles, S. J.; Hursthouse, M. B. J. Org. Chem. 2003, 68, 7880-7883. doi:10.1021/jo034981k

90. Dobbs, A. P.; Martinović, S. Tetrahedron Lett. 2002, 43, 7055-7057. doi:10.1016/s0040-4039(02)01558-7

91. Lian, Y.; Hinkle, R. J. J. Org. Chem. 2006, 71, 7071-7074. doi:10.1021/j0060738k

92. Cho, Y. S.; Karupaiyan, K.; Kang, H. J.; Pae, A. N.; Cha, J. H.; Koh, H. Y.; Chang, M. H. Chem. Commun. 2003, 2346-2347. doi:10.1039/b307320c

93. Dziedzic, M.; Lipner, G.; Furman, B. Tetrahedron Lett. 2005, 46, 6861-6863. doi:10.1016/j.tetlet.2005.08.014

94. Tay, G. C.; Huang, C. Y.; Rychnovsky, S. D. J. Org. Chem. 2014, 79, 8733-8749. doi:10.1021/jo501580p

95. Lu, J.; Song, Z.; Zhang, Y.; Gan, Z.; Li, H. Angew. Chem., Int. Ed. 2012, 51, 5367-5370. doi:10.1002/anie.201201323

96. Xu, Y.; Yin, Z.; Lin, X.; Gan, Z.; He, Y.; Gao, L.; Song, Z. Org. Lett. 2015, 17, 1846-1849. doi:10.1021/acs.orglett.5b00485

97. Zhao, X.-L.; Liu, L.; Chen, Y.-J.; Wang, D. Tetrahedron 2006, 62, 7113-7120. doi:10.1016/j.tet.2006.04.075

98. Miranda, P. O.; Ramírez, M. A.; Padrón, J. I.; Martín, V. S. Tetrahedron Lett. 2006, 47, 283-286. doi:10.1016/j.tetlet.2005.11.032

99. Miranda, P. O.; Ramírez, M. A.; Martín, V. S.; Padrón, J. I. Org. Lett. 2006, 8, 1633-1636. doi:10.1021/ol060247m

100.Scoccia, J.; Pérez, S. J.; Sinka, V.; Cruz, D. A.; López-Soria, J. M.; Fernández, I.; Martín, V. S.; Miranda, P. O.; Padrón, J. I. Org. Lett. 2017, 19, 4834-4837. doi:10.1021/acs.orglett.7b02270

101. Miranda, P. O.; Ramírez, M. A.; Martín, V. S.; Padrón, J. I. Chem. - Eur. J. 2008, 14, 6260-6268. doi:10.1002/chem.200800281

102.Dubost, C.; Markó, I. E.; Bryans, J. Tetrahedron Lett. 2005, 46, 4005-4009. doi:10.1016/j.tetlet.2005.04.041

103.Chan, K.-P.; Seow, A.-H.; Loh, T.-P. Tetrahedron Lett. 2007, 48, 37-41. doi:10.1016/j.tetlet.2006.11.023

104.Parida, B. B.; Lysenko, I. L.; Cha, J. K. Org. Lett. 2012, 14, 6258-6261. doi:10.1021/ol3030204

105. Lee, H. G.; Lysenko, I. L.; Cha, J. K. Angew. Chem., Int. Ed. 2007, 46, 3326-3328. doi:10.1002/anie.200700172

106.Zheng, K.; Liu, X.; Qin, S.; Xie, M.; Lin, L.; Hu, C.; Feng, X. J. Am. Chem. Soc. 2012, 134, 17564-17573. doi:10.1021/ja3062002

107.Pérez, S. J.; Purino, M.; Miranda, P. O.; Martín, V. S.; Fernández, I.; Padrón, J. I. Chem. - Eur. J. 2015, 21, 15211-15217. doi:10.1002/chem.201502488

108. Matsumoto, K.; Yanagi, R.; Yamaguchi, K.; Hayashi, E.; Yasuda, E.; Nokami, T.; Nishiwaki, K.; Kashimura, S.; Kuriyama, K. Heterocycles 2018, 96, 1363-1372. doi:10.3987/com-18-13940

109.Kumar, P.; Dey, R.; Banerjee, P. Org. Lett. 2018, 20, 5163-5166. doi:10.1021/acs.orglett.8b02094
110. Mullen, C. A.; Gagné, M. R. Org. Lett. 2006, 8, 665-668. doi:10.1021/ol052845r

111. Yu, B.; Jiang, T.; Li, J.; Su, Y.; Pan, X.; She, X. Org. Lett. 2009, 11, 3442-3445. doi:10.1021/ol901291w

112. Lalli, C.; van de Weghe, P. Chem. Commun. 2014, 50, 7495-7498. doi:10.1039/c4cc02826k

113. Liu, L.; Kaib, P. S. J.; Tap, A.; List, B. J. Am. Chem. Soc. 2016, 138, 10822-10825. doi:10.1021/jacs.6b07240

114.Sun, H.-R.; Zhao, Q.; Yang, H.; Yang, S.; Gou, B.-B.; Chen, J.; Zhou, L. Org. Lett. 2019, 21, 7143-7148. doi:10.1021/acs.orglett.9b02714

115. Tsui, G. C.; Liu, L.; List, B. Angew. Chem., Int. Ed. 2015, 54, 7703-7706. doi:10.1002/anie.201500219

\section{License and Terms}

This is an Open Access article under the terms of the Creative Commons Attribution License

(https://creativecommons.org/licenses/by/4.0). Please note that the reuse, redistribution and reproduction in particular requires that the author(s) and source are credited and that individual graphics may be subject to special legal provisions.

The license is subject to the Beilstein Journal of Organic Chemistry terms and conditions: (https://www.beilstein-journals.org/bjoc/terms)

The definitive version of this article is the electronic one which can be found at: https://doi.org/10.3762/bjoc. 17.77 